\title{
High-Frequency Trading Competition
}

\author{
Jonathan Brogaard and Corey Garriott*
}

\begin{abstract}
Theory on high-frequency traders (HFTs) predicts that market liquidity for a security decreases in the number of HFTs trading the security. We test this prediction by studying a new Canadian stock exchange, Alpha, that experienced the entry of 11 HFTs over 4 years. We find that bid-ask spreads on Alpha converge to those at the Toronto Stock Exchange as more HFTs trade on Alpha. Effective and realized spreads for non-HFTs improve as HFTs enter the market. To explain the contrast with theory, which models the HFT as a price competitor, we provide evidence more consistent with HFTs fitting a quantity-competitor framework.
\end{abstract}

\section{Introduction}

Competition in equity markets was once quite restricted. In the past, traders could access markets such as the New York Stock Exchange (NYSE) only by purchasing seat membership, a privilege that has cost millions of dollars. Membership allowed a trader to work on the exchange floor, watching the market directly and reacting immediately. As Ho and Stoll (1980) put it: "Because of his proximity to the market, the dealer would generally be expected to offer better prices than an ordinary investor faced with higher communication, waiting, and transfer cost." Membership thus limited competition to those who could pay.

Exchanges had to limit competition because they could accommodate only so many people on the premises. With the development of low-cost microelectronics, physical space is no longer a binding constraint. Space near a computer server is far less scarce than space on a trading floor, and accordingly, many exchanges

*Brogaard, jbrogaard@eccles.utah.edu, University of Utah Eccles School of Business; Garriott (corresponding author), cgarriott@bankofcanada.ca, Bank of Canada Financial Markets Department. We are grateful to Michael Brolley, David Cimon, Jennifer Conrad (the editor), Thierry Foucault, Bjorn Hagströmer, Terry Hendershott, Oleksiy Kryvstov, Albert Menkveld, Pamela Moulton, Christopher Parsons, Talis Putnins, Ryan Riordan, Gideon Saar, Mehrdad Samadi (the referee), and Joshua Slive for their many suggestions to improve the article; to seminar participants at the Canadian Economic Association, Canadian Imperial Bank of Commerce, Financial Risks International Forum, Ontario Securities Commission, Society for Financial Studies (SFS) Cavalcade, Stockholm Business School, Vienna High-Frequency Trading (HFT): Curse or Blessing, and the Western Financial Association; and to Adrian Eng and Faith Chin for their research assistance. This article is an extension of the Bank of Canada working paper by the same name. The views expressed in this paper are those of the authors. No responsibility for them should be attributed to the Bank of Canada. All errors are our own. 
offer electronic access to markets at much lower prices. ${ }^{1}$ The chief beneficiary of this democratization of competition has been the community of high-frequency traders (HFTs), private trading companies that now compete with major financial institutions (Jones (2013)).

One might expect fanfare associated with a decline in costs that opened markets to a new kind of trader. Instead, financial institutions have expressed concern about HFTs, in part due to frequent "flash-crash" events. ${ }^{2}$ In the academic literature as well, existing theory has negative conclusions for high-frequency competition in markets. A common concern is that HFTs trade mostly to "snipe" other market participants before they can remove stale prices. Menkveld and Zoican (2017) and Budish, Cramton, and Shim (2015) predict that as the number of HFTs rises, bid-ask spreads get no better or worse. ${ }^{3}$

In this article, we test the theoretical predictions using a sample of data uniquely suited to document what happens as the number of HFTs increases. The data set comes from Alpha, a new Canadian stock market that started the sample with no HFT presence and experienced the arrival of multiple HFTs over 4 years. The scenario enables us to observe the impact on liquidity in a market as its industrial organization transitions from no HFTs to many HFTs. The data set includes complete order-book data with counterparty information. To identify the impact of competition on liquidity, we use a difference-in-differences event study on markets for 279 stocks that saw a steady, staggered entry of 11 HFTs during the 4-year sample.

We find that HFT competition improves liquidity. For the first 5 months of the sample, bid-ask spreads on Alpha were worse than those on its larger rival, the Toronto Stock Exchange (TSX). Then, a series of HFTs began trading on Alpha and brought its spreads in line with the larger market. Using the event study, we find that HFT entry leads to better liquidity metrics for non-HFTs trading on Alpha. The result contrasts with theory, and we explain the contrast by showing that the data are not easy to reconcile with an assumption underpinning the theory, which is that the HFT is a price competitor. We conclude that wider electronic access to equity markets is good for liquidity, whereas barriers to entry could limit the benefit.

Our data come from Alpha, which was one of the first equity alternative trading systems (ATSs) in Canada and became a listing exchange in 2012. As an ATS founded in 2008, Alpha was a member of the wave of new trading venues that launched in the 2000s in the United States, Europe, and Canada after regulatory changes allowed for more trading outside of the primary stock exchange. Alpha was the most successful Canadian ATS by volume, exceeding a $20 \%$ volume share in Jan. 2010. Because Alpha was a successful ATS, its data can provide a good test of the importance of industrial organization within a single market.

\footnotetext{
${ }^{1}$ For example, the NYSE charges an initial co-location fee of $\$ 5,000$ per cabinet with a monthly fee depending on electricity usage. See https://www.nyse.com/publicdocs/nyse/markets/nyse/NYSE_ Price_List.pdf, p. 21.

${ }^{2}$ See "Market Participants' Concerns" in remarks by Fischer (2016).

${ }^{3}$ Proposition 2.2 of Menkveld and Zoican (2017) predicts that bid-ask spreads get worse in the number of HFTs; proposition 1.i of Budish et al. (2015) predicts that HFT competition creates a nonzero spread but one invariant to the number of HFTs.
} 
The data contain complete order-book information and an anonymous counterparty code that distinguishes unique direct-access members. The counterparty codes on Alpha enable the empirical identification of HFTs using the firms' inventory and trading behavior. The firms in the sample have an advantageous sequence of entry for the study. There were no HFTs during the first 5 months, and then 11 firms steadily enter during the time period Nov. 2008-Sept. 2012.

The essence of our results can be seen in Figure 1, which compares bid-ask spreads on Alpha to the TSX as sequential HFTs start trading stocks on Alpha. As presented in the figure, if a firm is the second to arrive, bid-ask spreads on Alpha tighten but do not reach the level of the TSX. The same is true if the firm is the third to arrive. Four firms must begin trading before Alpha bid-ask spreads resemble the TSX. We interpret the graph as prima facie evidence that liquidity improves in the number of HFTs trading at a market.

To establish identification, we run a difference-in-differences event study on HFT entry events. An HFT entry event is the first day an HFT trades material volume (1,000 shares) of a stock. To focus on permanent changes in the industrial organization, we select entry events in which the entrant continues trading the stock through a 3-month study window. To control for any liquidity trends on Alpha, given it was a growing stock market, we match Alpha stocks to other Alpha stocks.

Event-study methodology requires the events to be exogenous to the variables of interest during the event window of the study. This is likely in our scenario because HFTs were attracted to Alpha because of the wide spreads and low competition compared with other markets, meaning they were attracted by long-term profit opportunities. Indeed, we can predict how many HFTs eventually enter a stock on Alpha using the stock's long-term characteristics. However, we find little evidence that the timing of entry can be explained during the event windows of the study, meaning that HFTs are not apparently timing their entry based

\section{FIGURE 1}

Bid-Ask Spreads on Alpha and the TSX, Before and After HFT Entry

Figure 1 compares the average bid-ask spreads for stocks on Alpha and the Toronto Stock Exchange (TSX) averaged during the 1 month before and after high-frequency trader (HFT) entry dates for the stocks. An HFT entry date for a stock is the first day an HFT trades at least 1,000 shares of the stock on Alpha. Bid-ask spreads for Alpha stocks were computed using order-book data granted by Alpha; for the same stocks, TSX bid-ask spreads were computed using Thomson Reuters Tick History. The chart shows the stock-event averages before and after the second HFT to enter the market enters, before and after the third entrant, and before and after the fourth or greater entrant.

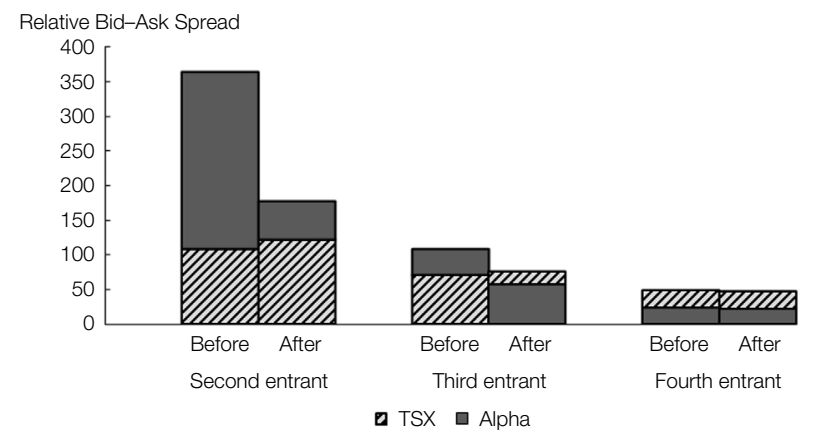


on short-term market conditions. Entry cannot be predicted using daily, weekly, and monthly levels and differences in spreads, volatility, and volumes from Alpha and the TSX. Although entry is endogenous to the long-term industrial organization, the evidence does not suggest that HFTs enter due to temporary variation in liquidity conditions.

We evaluate passive and aggressive HFTs separately so that we can distinguish between the effect we expect each type to have. Passive HFT strategies, those that use primarily limit orders, are associated with liquidity supply strategies (Aït-Sahalia and Sağlam (2013), Hoffmann (2014)). Therefore, we expect that as passive HFTs enter and compete with each other, liquidity will improve. Aggressive HFT strategies, those that use primarily marketable orders, are associated with short-lived arbitrage opportunities (Biais, Foucault, and Moinas (2015)). If liquidity takers are merely aggravating frictions associated with delays in information dissemination, we expect liquidity to deteriorate.

Our highlighted results are presented as follows: First, we begin with graphical evidence. Figure 1 shows that spreads on Alpha converge to those at the TSX as more HFTs trade, and Figure 4 shows that spreads also improve in the Herfindahl-Hirschman index of HFT competition. Having presented graphical evidence, we next use the event study to estimate the impact of HFT entry on execution costs for non-HFT traders. For entrants that use mostly passive orders, we find that costs improve. For entrants that use mostly aggressive orders, we find minor evidence of improvement. Unlike the dealers noted by Ellis, Michaely, and O'Hara (2002), HFT competition has meaningful long-term impact. In separate regressions on the first, second, and third months after entry, entrants that use passive orders improve liquidity through time.

Our results use data from the Canadian Alpha exchange and an empirical definition of HFTs, so we cannot infer that they apply universally. Still, the findings contrast with existing models of HFT competition. In existing models, HFTs that use passive orders have no impact on liquidity, and HFTs that use aggressive orders make liquidity worse. We find instead that passive HFT entry improves liquidity and that aggressive HFT entry leads to no identifiable harm.

In our view, the models make predictions contrasting with the data because of their assumptions about the industrial organization. Liquidity supply is assumed to be price competitive, meaning that successive HFT entrants have nothing to contribute to liquidity by definition. An alternative tradition in market microstructure assumes that competition can have a positive role because the industry is quantity competitive (Kyle (1989), Subrahmanyam (1991), Biais, Martimort, and Rochet (2000), and Bondarenko (2001)). We find that the data are more consistent with the HFT being a quantity competitor. The data support three predictions about firm entry that are typical of quantity competition but that are inconsistent with simple price competition: Entry enlarges the market, entrants seize market share from incumbents, and entry leads incumbents to lower prices. Because we lack data on costs at HFTs, we cannot reject conclusively the assumption of price competition, but we can show that the data are easier to explain from the perspective of quantity competition.

The findings contribute to empirical work on HFTs and competition. Breckenfelder (2013) and Boehmer, Li, and Saar (2018) study variation in HFT 
presence in an equilibrium setting in markets that have the equilibrium number of HFTs. We differ by focusing on long-term changes to the market structure, which allows us to focus on conclusions regarding industrial organization rather than those on HFTs' response to market conditions. Our article complements that of Menkveld (2013), who studies a single HFT entry event in detail. Whereas Menkveld (2013) focuses on liquidity supply following the entrance of one HFT, we investigate how existing HFTs respond as new HFTs entrants arrive to the market.

A related article by Baron, Brogaard, Hagströmer, and Kirilenko (2019) also studies the implications of HFT competition. Whereas our article argues that HFT competition is good for market liquidity, Baron et al. (2019) argue that the environment that generates HFT competition is fragile. In this article, we conclude that HFT competition can reduce HFT revenues, whereas Baron et al. (2019) argue that competition among HFTs is limited by relative speed, and as a result, HFT profits remain high. Baron et al. (2019) would suggest that when the Alpha market has matured, HFT profits would still be higher than one would predict if Alpha were a perfectly competitive marketplace.

\section{Data}

The data for this study come from the Canadian stock exchange Alpha. Alpha opened for trade in Nov. 2008. In Jan. 2009, Alpha grew to host the second-largest share of trading volume in Canada, and in Jan. 2010, it hosted 20\% of Canadian trading volume. Alpha was an ATS until Apr. 2012, when it became a listing exchange. It was independently operated until merging with the TMX Group as part of the Maple transaction in Aug. 2012.

Alpha provided order-book data from its first day of business, Nov. 7, 2008, to Sept. 25, 2012. The data contain all limit-order inserts, updates, fills, and cancels with millisecond timestamp, side, and initiation. To focus on larger stocks, we sample only stocks that have both more trading volume and a higher market capitalization than the least-traded and least-capitalized stock in the Standard \& Poor's (S\&P) TSX 60 index as of Sept. 2012. Figure 2 displays the time-series distribution of overall equity-trading volume for the 279 stocks sampled in this study.

Each order contains an anonymous counterparty field populated by an Alpha employee on an ad hoc basis based on Alpha's internal knowledge of its customer base. The field consists of numerical codes giving three pieces of counterparty information: a code identifying orders from known smart-order routers, a code identifying the known brand of order-management system used to disseminate an order, and an anonymous code identifying a known unique direct-access market participant (distinguished from its broker). The code allows us to identify the date each direct-access market participant begins trading.

Our counterparty identification is confined to Alpha, so we do not track the activities of an HFT across markets. Although questions about cross-market competition are interesting, the instrument of increasing HFT participation in one market is sufficient for our research question. In equity markets, the trading platform is the basic market structure at which open trading occurs. To provide a 
FIGURE 2

Trading Volume in Canada and Alpha's Share

Figure 2 plots the monthly dollar-volume market share of Alpha for the sample stocks during the sample period and the total dollar volume of the sample stocks on all Canadian exchanges, including Alpha. The data were computed using Bloomberg daily trading volumes for the stocks.

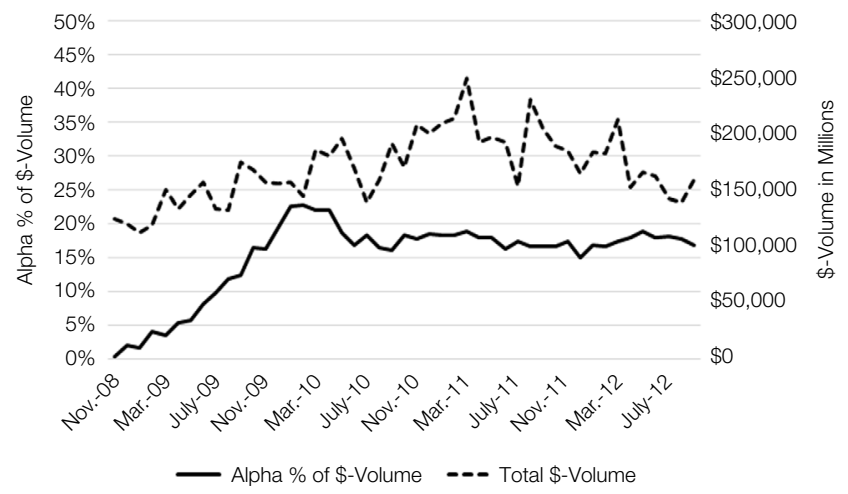

market-wide view, we draw additional data on TSX prices, volumes, and bid-ask spreads from Bloomberg, and we compare liquidity conditions on Alpha to the TSX as HFTs enter.

\section{A. Identifying HFTs}

To identify HFTs, we first exclude smart-order routers and firms that use order-management systems. For the remainder, we use criteria from the literature to distinguish HFTs from other algorithmic traders (Kirilenko, Kyle, Samadi, and Tuzun (2017)). An HFT must carry less than $15 \%$ of its daily volume overnight and must switch signs at least $40 \%$ of the time for a contiguous 2 weeks of trading days. The first criterion distinguishes HFTs from algorithmic execution because HFTs should not build a position. The second criterion distinguishes HFTs from strategies that bear substantial price risk overnight. A firm code marked as an HFT for any stock is marked as an HFT for every stock. The criteria identify 11 firms as HFTs.

The inventory threshold is above $0 \%$ because there are multiple markets for the stocks traded on Alpha. An HFT may open a position on one venue and close it on another, resulting in what would appear to be an inventory position from the researcher's perspective even if the trader is net neutral.

Theory on HFT competition distinguishes between HFTs that trade passively and HFTs that trade aggressively. In the models, at most, one HFT engages in a price-competitive strategy of market making, and the others choose to adversely select market makers using aggressive trades. To address the theory, we study both strategies separately. Passive HFT strategies, namely, those that use primarily limit orders, are associated with liquidity supply strategies (Aït-Sahalia and Sağlam (2013), Hoffmann (2014)). We identify an entrant as passive if it trades passively two-thirds of the time. We expect that as passive HFTs enter and compete with each other, liquidity will improve. Aggressive HFT strategies, namely, those that use primarily marketable orders, are associated with short-lived 
arbitrage opportunities (Biais et al. (2015)). We identify an entrant as aggressive if it trades aggressively two-thirds of the time. If liquidity takers merely aggravate frictions associated with delays in information dissemination, we expect liquidity to deteriorate. The identification of passive and aggressive is done on a stock-entry basis, so the same firm can be a different type on two different stocks.

\section{B. Identifying HFT Entry Dates}

The stock-entry date of an HFT is the calendar date on which a firm first trades at least 10 lots (1,000 shares) on Alpha and does not stop trading for 3 months, the size of our post-period treatment window. The threshold of 10 lots is greater than the trade-size minimum of 1 lot to exclude days on which the participant is merely testing its connection. HFTs in the data that delay their next day of trade in a stock do so by a median of 6 days; of the firms that delay, all of them trade only 100 shares on their first day. We study only first entries.

Entry events are specific to the stock and HFT, so the same HFT can have different entry dates for different stocks. There is variation in how many stocks an entrant begins trading or stops trading at a time. Most entrants start trading several stocks on the same day. The day an HFT begins trading, it starts trading a median of 7 stocks and a mean of 20.6 stocks. The largest number of stocks a firm begins trading on the same day is 81 . Figure 3 gives more information on variation in HFT presence in the sample.

Graph A of Figure 3 plots the average number of HFTs per stock during the sample. The statistic remains at 0 during the first 5 months and then increases at a linear rate to the sample end. We interpret this as evidence that the industrial organization on Alpha is evolving during the sample, and the number of HFTs does not reach an equilibrium during the sample period. Graph B gives a histogram of the entry dates in bins of 1 day. Entries are distributed throughout the 4-year window, providing a time-series control. Some HFTs choose to enter multiple stocks on the same day, whereas others stagger their entries to a few stocks at a time.

\section{Summary Statistics}

Table 1 provides summary statistics for the HFT entries. Each row of the table gives the average, standard deviation, 25 th percentile, median, and 75 th percentile statistics of various measures. DAILY_VOLUME is the average number of shares the entrant traded daily. DAILY_TRADES is the average number of trades the entrant executed daily. \%DAILY_VOLUME is the average percentage of total daily volume the entrant contributed. \%VOLUME_OVERNIGHT is the average percentage of its own daily volume the entrant held at the end of the day. SWITCHING_RATE is the percentage of the entrant's trades for which the entrant switched the direction of its trade, the percentage of the time it bought after it had sold or sold after it had bought. \%PASSIVE is the percentage of the entrant's trades for which the entrant initiated the trade. EVENTS is the number of HFT events.

There are 1,121 HFT entries, of which 641 are passive and 368 are aggressive; 112 HFT entries fit neither the passive nor the aggressive definition. During the month after entry, entrants trade on average 20,991 shares a day, which is $6.7 \%$ of daily volume. Passive HFTs trade more than aggressive, with 24,208 shares 
FIGURE 3

HFT Presence on Alpha

Figure 3 shows two measures of high-frequency trader (HFT) presence on Alpha: the average number of HFT per stock in the sample and a histogram of entry dates. Graph A shows the average number of HFTs that traded a stock per stock, for each day in the sample. Graph B shows a histogram of the number of HFT entry dates in bins of 1 day. There are 1,121 entry events, of which there are 1,008 events in which there is at least one incumbent HFT.
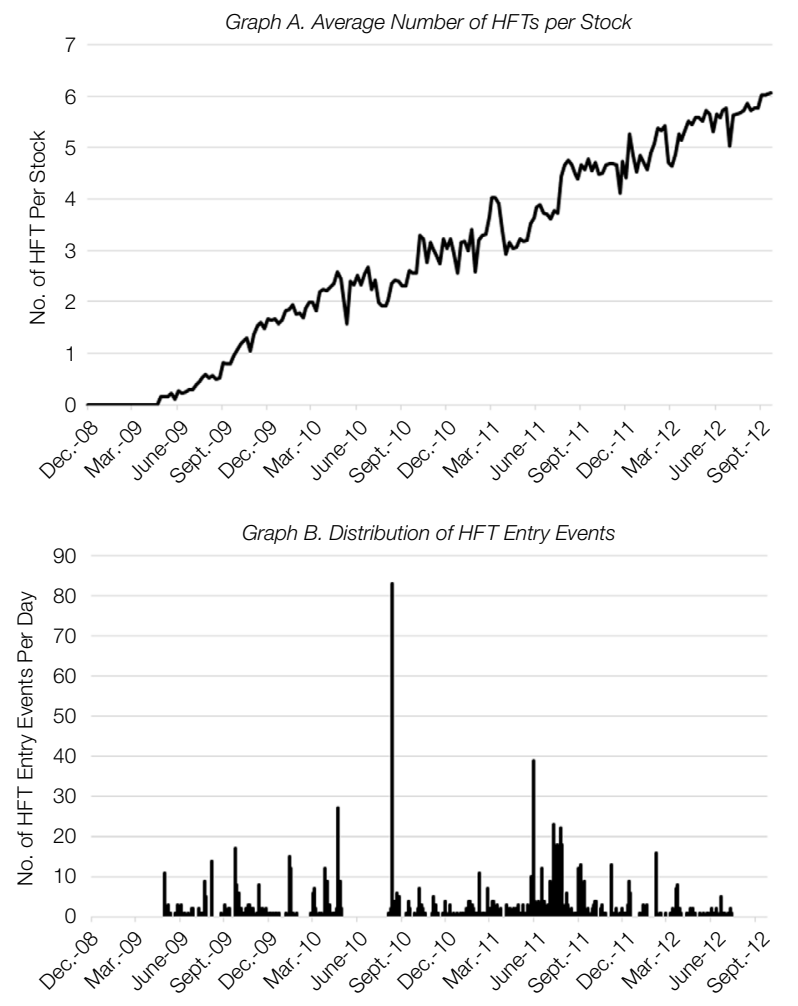

(9.1\% of volume) compared with 12,135 shares (3.8\%). This fits the nature of aggressive strategies, which are more opportunistic than continuous. A majority of entrants hold less than $16 \%$ of their volume overnight and switch their trade sign at least $41 \%$ of the time.

Table 2 reports summary statistics by the number of incumbents present at entry. The columns report means and standard deviations of various statistics, and the rows segment the measures by the number of incumbents present at entry. Events are grouped by the median daily number of HFTs incumbent during the month before entry.

Entrants to stocks with few incumbents generate more daily volume than entrants to stocks with many incumbents. Entrants to stocks with no incumbents trade on average 31,023 shares (16.9\% of daily volume), whereas entrants to stocks with 6 or more incumbents trade on average 10,365 shares (1.5\%). The statistics are consistent with a market growing crowded. Entrants become more aggressive in the number of incumbents, although stocks with 6 or more 
FIGURE 4

\section{Herfindahl-Hirschman Index and Bid-Ask Spreads}

Figure 4 plots the average daily bid-ask spread prevailing on Alpha stocks by sample deciles of the HerfindahlHirschman index for the high-frequency traders (HFTs) trading the stocks. The Herfindahl-Hirschman index is a measure of competition and is equal to the sum of the firms' squared market shares of daily trading volume (double-counted). Bid-ask spreads were computed using order-book data granted by Alpha and were computed once per calendar date and averaged by decile.

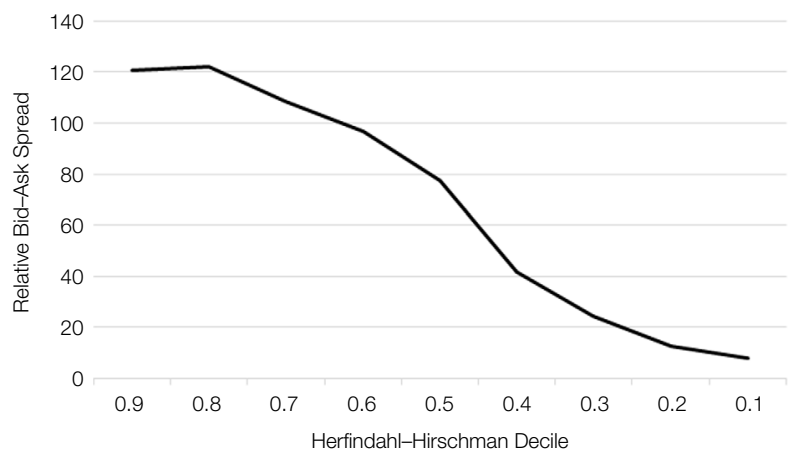

TABLE 1

\section{Summary Statistics for HFT Events}

Table 1 gives sample summary trading data for the high-frequency trader (HFT) entrants during the month after their entry. DAILY_VOLUME is the average number of shares the entrant traded daily. DAILY_TRADES is the average number of trades the entrant executed daily. \%DAILY_VOLUME is the average percentage of total daily volume the entrant contributed. \%VOLUME OVERNIGHT is the average percentage of its own daily volume the entrant held at the end of the day. SWITCHING_RATE is the percentage of the entrant's trades for which the entrant switched the direction of its trade, buying after it had sold or selling after it had bought. \%PASSIVE is the percentage of the entrant's trades for which the entrant initiated the trade (through either a market order or a marketable limit order).

Mean

Std. Dev.

$\underline{P 25}$

Median

Panel A. All HFT Entries

DAILY_VOLUME

DAILY TRADES

\%DAILY_VOLUME

\%VOLUME_OVERNIGHT

SWITCHING_RATE

\%PASSIVE

No. of events

$\underline{\text { Panel B. Passive HFT Entries }}$

DAILY VOLUME

DAILY TRADES

\%DAILY_VOLUME

\%VOLUME OVERNIGHT

SWITCHING_RATE

\%PASSIVE

No. of events
20,991

79

6.7

30

55

1,121

\section{4,208}

72

9.1

30

37

93

641

\begin{tabular}{|c|c|c|c|c|c|}
\hline DAILY_VOLUME & 12,135 & 26,139 & 1,200 & 3,900 & 12,000 \\
\hline DAILY_TRADES & 74 & 134 & 8 & 27 & 79 \\
\hline \%DAILY_VOLUME & 3.8 & 4.9 & 0.7 & 2.1 & 5.1 \\
\hline \%VOLUME_OVERNIGHT & 30 & 35 & 1.4 & 12 & 50 \\
\hline SWITCHING_RATE & 42 & 27 & 23 & 43 & 59 \\
\hline \%PASSIVE & 3.4 & 15 & 0 & 0 & 0 \\
\hline No. of events & 368 & & & & \\
\hline
\end{tabular}

80,761

153

10

34

23

45

90,876

144

13

32

20

16

1,100
7
0.8
3.4
25
0

0

1,100
7
0.9
5.9
26
93

4,100

21

3.3

17

41
100

17,700

68

11

42

50
100

\section{Panel C. Aggressive HFT Entries}


TABLE 2

Summary Statistics for HFT Events, by Number of Incumbents

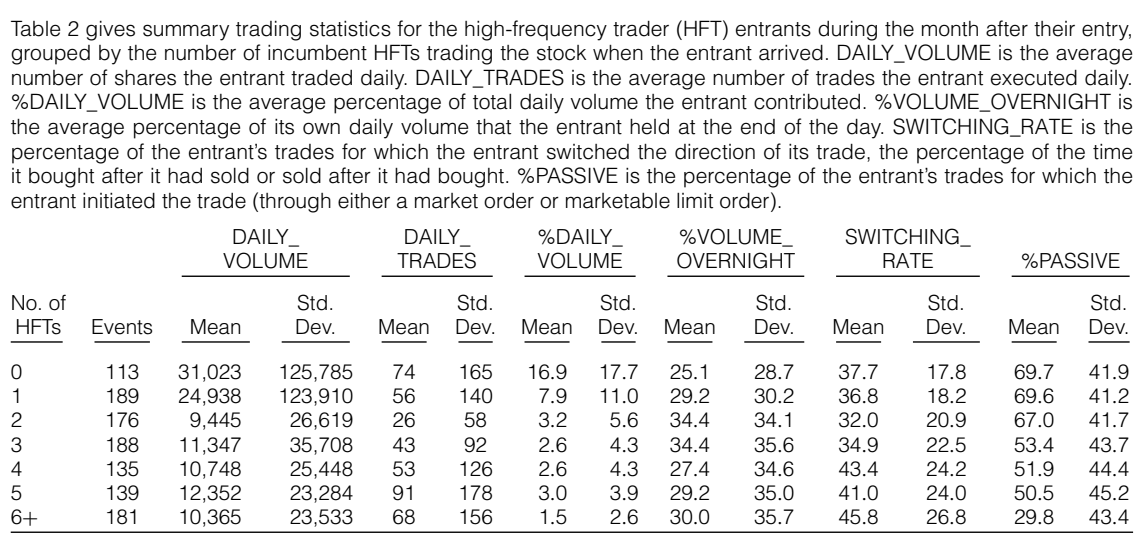

HFTs still experience passive entrants. Table 2 shows a contrast with theory, in which one HFT acts as a market maker and all subsequent HFTs are aggressive.

\section{Methodology}

This article uses the difference-in-differences (DID) event-study methodology. For each HFT event, we collect daily averages of data for variables of interest for the treatment stock during a pre-event window of 1 month before the event and during 3 successive 1-month windows after the event. These are the treatment-stock observations.

For each treatment stock observation, we include contemporaneous observations from a matched control stock not experiencing an HFT event. The eligible control stocks are other stocks trading at Alpha. We match Alpha stocks to Alpha stocks rather than to the same stocks at the TSX because it might be argued that there are trends on Alpha, a growing exchange. When matching controls to treatments, we remove candidate controls that experience an HFT event in a 1-month centered window around the treatment-stock event date. This excludes stocks experiencing a contemporaneous HFT entry by any HFT. Because there are so many entries, we do not exclude control stocks experiencing HFT entry in the second or third month after the treatment-stock event date because it would eliminate all candidate control stocks for certain events. This renders our results more conservative.

The control observations are selected by the Mahalanobis distance from the treatment stock's log average market capitalization, log average trading volume, average closing price, average 10-day daily price volatility, and average absolute bid-ask spread, all measured during the month preceding the entry-event date. Any match assignments in which the same control would be assigned to more than one treatment stock with the same event date are resolved using the GaleShapley algorithm. To eliminate outliers, observations are winsorized within each 1-month window at 3 standard deviations from the window average. 
The DID regression model is as follows:

$$
\operatorname{MEASURE}_{i, j, t}=\beta \mathrm{HFT}_{i, j, t}+\gamma \mathrm{AFTER}_{i, t}+\delta \mathbf{X}_{i, j, t}+\theta \mathbf{F E}_{i, j}+\epsilon_{i, j, t},
$$

where $i$ is an index marking the HFT event; $j$ is an index marking the treatment stock or the control stock for that event; $t$ is the index for the date in event time (days before or after the event); HFT is the variable of interest and is an indicator variable equal to 1 for treatment-stock dates after the new HFT entered, and 0 otherwise; AFTER is an indicator variable equal to 1 after the date of the HFT entry for HFT event $i$, and 0 otherwise; $\mathbf{X}$ is a vector of control variates; and FE is a vector of stock-event-level fixed effects. There is a unique fixed effect for each event-stock interacted, not one for each event and each stock.

The first difference is time, before and after the entry, and is captured by the AFTER variable. The second difference is treatment versus control stock. The interaction, which is the liquidity change in the treatment stock after HFT entry, is captured by the HFT variable. The control variates are known determinants of liquidity: MARKET_CAPITALIZATION is the number of shares outstanding for the stock multiplied by its share price. TSX_VOLUME is the stock's daily trading volume on the TSX obtained from Bloomberg. PRICE is the average daily midquote for the stock on Alpha. VOLATILITY is the 10-day moving average of the standard deviation of the closing price, also obtained from Bloomberg.

To distinguish the entry effect of an HFT from the entry effect of any firm unconditionally, we include a control for the industrial organization (O'Hara, Saar, and Zhong (2019)). In each regression specification, we include the variable NUMBER_OF_FIRMS, which captures the number of unique participants trading stock $j$ on day $t$. By including this variable, we disentangle the impact of an HFT entrant from the unconditional effect of adding any participant.

Because this is a study on HFT competition, we do not study what happens when an HFT begins trading a stock that is otherwise devoid of HFTs on the Alpha exchange (and hence exhibits no HFT competition). This has the benefit of eliminating entry events from the early part of our sample period, the first half of 2009, during which Alpha was growing quickly. The emphasis on competition distinguishes this article from that of Menkveld (2013), which focuses on how the market as a whole responds to a single HFT entrant.

The regression is conducted in two ways. First, it is carried out using ordinary least squares (OLS). Second, we use a weighted-least-squares (WLS) regression specification. The latter choice is because we expect more active entrants to have a greater effect. The weight is based on the ex ante expected size of the entrant. The ex ante weighted approach predicts HFT volume share using the levels of the stock characteristics before entry. The predictive model is a regression of the log HFT percentage share on the average log volume, stock volatility, and a stock fixed effect, and it achieves an $R^{2}$ of 0.384 . We use the predicted HFT percentage share from this model as the observation weight. The weighting diminishes the influence of HFT events for which the HFT is not expected to contribute much volume and therefore would have a weaker influence on stock liquidity. Standard errors are double-clustered by stock-event and by calendar date (Bertrand, Duflo, and Mullainathan (2004), Petersen (2009), and Thompson (2011)). 
We estimate three treatment effects, one for each month after the entry: the immediate month after, the time period 1-2 months after, and the time period 2-3 months after. The different periods of time provide evidence on whether the observed finding is transitory or permanent.

\section{Does HFT Competition Improve Liquidity?}

\section{A. Suggestive Evidence}

We begin with graphical evidence that HFT competition is positively associated with liquidity. In Figures 1 and 4, greater competition is associated with tighter Alpha bid-ask spreads, which converge to contemporaneous levels at the TSX. We interpret this as prima facie evidence that HFT competition benefits liquidity.

Figure 1, in the Introduction, compares the average bid-ask spreads of Alpha stocks to the same stocks trading on the TSX during a 2-month window centered on HFT entry events. In the first two columns, the entry of a second HFT liquidity supplier tightens spreads on Alpha but not to the levels of the more liquid TSX. In the second two columns, spreads on Alpha after the third firm enters are still on the order of 175 basis points (bps), compared with $100 \mathrm{bps}$ at the TSX. The third set of columns shows that it takes 3 HFTs before bid-ask spreads on Alpha converge to the TSX, averaging around $50 \mathrm{bps}$.

If HFT competition did not benefit liquidity, one would expect that a second HFT on Alpha would have no effect on Alpha's spreads. Instead, we find that many are necessary. To confirm the observed positive relationship between competition and liquidity, in Figure 4 we plot average Alpha spreads in the deciles of an HFT competitiveness measure. The measure is the Herfindahl-Hirschman index, the sum of the squared volume share of each HFT firm. A smaller index value implies greater competition. As in Figure 1, each competition decile is associated with tighter Alpha spreads.

\section{B. Identification Conditions of the DID Event Study}

To identify the effect of competition on liquidity, we implement a DID event study using the HFT entry dates as the events. Event-study methodology requires that the events are exogenous to the variables of interest within the time frame of the event study. We test this condition by attempting to explain the timing of HFT entry using variables that are empirically related to HFT entry decisions. Although HFT presence in our sample can be explained in the long term by variables related to the profitability of market making, the timing of entry cannot be explained at time frames relevant to the study. This reduces concerns that a latent trend during the event window is co-determining both HFT entry and shifts in market quality.

HFT entry is not random; HFTs choose to trade stocks because they expect to make a profit. Using an ordered probit model, we show that variables related to the profitability of market making can be used to predict the number of HFTs trading a stock. We use variables on volume, liquidity, and price volatility because HFTs' profits are related to the amount of round-trip trades they expect to complete, their ability to enter and exit positions, and the movement in the price. To ensure we are measuring the long-term or permanent characteristics of a stock, we model the 
number of HFTs trading an Alpha stock at the end of the sample (in either 2011 or 2012) as a function of the averages of the variables on the TSX at the beginning of the sample (in either 2009 or 2010), using the ordered probit model:

$$
\operatorname{Pr}\left(\mathrm{NUM} \_\mathrm{HFT}_{i, t}=i \mid X_{i, t}\right)=\operatorname{Pr}\left(\alpha_{i-1}<\beta X_{i, t}+\epsilon_{i} \leq \alpha_{i}\right),
$$

where $i$ indexes the stock; $t$ indexes the year; NUM_HFT is the median number of HFTs trading the stock on Alpha in year $t ; X_{t}$ represents the predictive variables, namely, the stock's average TSX_VOLUME, average bid-ask spread (TSX_SPREAD), and daily return VOLATILITY in year $t$, which are assumed to be normally distributed. We truncate NUM_HFT at 3 HFTs to reduce the size of the reported table. Therefore, the dependent variable can take the values of 0,1 , 2, and 3; statistical significance improves if NUM_HFT is untruncated. Variables are scaled by multiples of 10 so that the coefficients of regression are of order 1 . The results are reported in Table 3.

We find that HFT entry to Alpha is not random. Levels of volume, liquidity, and price volatility on the TSX in 2009 can predict $23.9 \%$ of the variation in the number of HFTs on Alpha stocks in 2012 with statistical significance; in the best specification, $40.6 \%$ of the variation in 2011 can be explained using the variables from 2010. The results are consistent with findings from other markets, in which HFTs are found to trade higher-volume stocks that have frequent price movements (Brogaard, Hendershott, and Riordan (2014)). When HFTs expand to Alpha, they most frequently enter stocks that have the long-term characteristics known to be good for HFT profitability.

TABLE 3

Prediction of Number of HFTs

Table 3 gives the coefficients obtained from an ordered probit regression of the number of high-frequency traders (HFTs) trading an Alpha stock in 2011 or 2012 on its characteristics in 2009 or 2010. The dependent variable takes the value of 0 for 0 HFTs trading the stock, 1 for 1 firm, 2 for 2 firms, and 3 for 3 or more firms. TSX_VOLUME is the daily average trading volume for a stock trading on the Toronto Stock Exchange (TSX) (divided by $10,000,000$ so that the coefficient has an order of 1) obtained from Bloomberg. TSX_SPREAD is the daily average bid-ask spread for a stock trading on the TSX (divided by 1,000) obtained from Thomson Reuters Tick History. VOLATILITY is the daily average return volatility for a stock trading on the TSX (multiplied by 10) obtained from Bloomberg. Standard errors are given in parentheses; *, ${ }^{* *}$, and ${ }^{* * *}$ indicate statistical significance at the $10 \%, 5 \%$, and $1 \%$ levels, respectively.

\begin{tabular}{|c|c|c|c|c|}
\hline \multirow{3}{*}{2009 TSX_VOLUME } & \multicolumn{4}{|c|}{ Number of HFTs in Year } \\
\hline & 2011 & 2012 & 2011 & 2012 \\
\hline & $\begin{array}{l}17.98^{* * *} \\
(5.01)\end{array}$ & $\begin{array}{l}8.74^{* * *} \\
(3.00)\end{array}$ & & \\
\hline 2009 TSX_SPREAD & 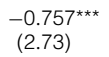 & $\begin{array}{c}-1.10^{\star \star *} \\
(3.77)\end{array}$ & & \\
\hline 2009 VOLATILITY & $\begin{array}{l}2.04^{* *} \\
(2.55)\end{array}$ & $\begin{array}{l}1.89^{* *} \\
(2.23)\end{array}$ & & \\
\hline 2010 TSX_VOLUME & & & $\begin{array}{l}29.15^{\star \star \star} \\
(6.07)\end{array}$ & 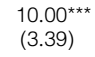 \\
\hline 2010 TSX_SPREAD & & & $\begin{array}{c}-5.72^{\star \star \star} \\
(7.46)\end{array}$ & $\begin{array}{c}-5.14^{\star \star *} \\
(7.59)\end{array}$ \\
\hline 2010 VOLATILITY & & & $\begin{array}{c}0.08 \\
(0.37)\end{array}$ & $\begin{array}{c}-0.11 \\
(0.49)\end{array}$ \\
\hline $\begin{array}{l}\text { Threshold } 1 \\
\text { Threshold } 2 \\
\text { Threshold } 3\end{array}$ & $\begin{array}{r}-1.47 \\
-0.44 \\
0.36\end{array}$ & $\begin{array}{l}-1.66 \\
-0.99 \\
-0.37\end{array}$ & $\begin{array}{r}-2.31 \\
-0.86 \\
0.11\end{array}$ & $\begin{array}{l}-2.53 \\
-1.56 \\
-0.89\end{array}$ \\
\hline $\begin{array}{l}\text { No. of obs. } \\
\text { Pseudo- } R^{2}\end{array}$ & $\begin{array}{r}212 \\
0.289\end{array}$ & $\begin{array}{r}212 \\
0.239\end{array}$ & $\begin{array}{r}244 \\
0.406\end{array}$ & $\begin{array}{r}244 \\
0.306\end{array}$ \\
\hline
\end{tabular}


We apply an expanded set of variables at higher frequencies to try to predict the timing of the HFT entry dates. If HFTs time their entries to take advantage of short-term opportunities or as a response to recent changes in markets, then the experimental design would be less able to distinguish an entry effect from related trends. We model the timing of entry using a probit model, and we attempt to predict the entry events in three ways: with daily, weekly, and monthly variation in predictive variables. We enlarge the set of predictive variables to include both levels and first differences, and we include values from both Alpha and the TSX. The model is as follows:

$$
\operatorname{Pr}\left(\mathrm{EVENT}_{i, t}=1 \mid X_{i, t-1}\right)=\Phi\left(\beta X_{i, t-1}+\epsilon_{i, t}\right),
$$

where $i$ is the stock index, $t$ is the time index, $\Phi$ is the normal cumulative distribution function (CDF), $X$ is the matrix of predictive variables, and $\epsilon$ is the error term. ENTRY takes the value of 1 for a stock-period in which at least one HFT enters, and 0 otherwise. We use both the 1-period lagged levels and the 1-period lagged first differences of each variable. The level variables are averaged over the previous day, week, or month. The first differences subtract the average value of the level variable from the previous average level.

The variables are as follows: CANADIAN_VOLUME, the log daily Canadian trading volume for the stock (divided by 100) obtained from Compustat; ALPHA_VOLUME, the log daily trading volume for a stock on Alpha (divided by 100); VOLATILITY, a 10-day moving average of the standard deviation of a stock's closing price obtained from Bloomberg; ALPHA_RELATIVE_SPREAD, the time-weighted average difference between the best bid and ask price divided by the midquote on Alpha (multiplied by 10,000); and TSX_RELATIVE_SPREAD, the time-weighted average difference between the best bid and ask price divided by the midquote on TSX (multiplied by 10,000). The results are reported in Table 4 .

HFT entry in our sample is not apparently driven by the predictive variables at frequencies relevant to the study window (which compares the 1 month before entry to one of 3 months after entry). The best specification predicts just $4 \%$ of the variation in HFT entry dates. A few specific estimates stand out. The level of the TSX relative bid-ask spread is predictive, with HFTs more likely to enter lower-spread stocks. The first difference of volatility is predictive for entries at a monthly frequency, meaning entry to stocks that have increasing volatility is less likely. Because the $R^{2}$ is so low, we regard the model as failing to offer a material explanation of the timing of entry. In our interpretation, this is because firms are entering for long-term reasons and not short-term reasons. The sample begins with no HFTs, and firms enter to take advantage of a relatively less developed industrial organization. ${ }^{4}$

The lack of time-series predictability reduces concerns that entry is driven by a trend in a latent variable that at the same time influences stock liquidity. Of course, the evidence cannot eliminate every concern because it is challenging

\footnotetext{
${ }^{4}$ In the Supplementary Material, we perform a similar analysis using a hazard model. One disadvantage of the tradition of hazard models is that they do not easily permit the use of the time series to predict entry.
} 
TABLE 4

\title{
Prediction of Timing of HFT Entry
}

\begin{abstract}
Table 4 gives the coefficients and 1-standard-deviation marginal effects obtained from probit regressions. The dependent variables take the value of 1 for a high-frequency trader (HFT), and 0 otherwise. Column 1 uses stock-day observations, column 2 uses stock-week observations, and column 3 uses stock-month observations. The level variables are averaged over the previous day, week, or month. The first differences subtract the average twice-lagged value of the level variable from the first-lagged value. CANADIAN_VOLUME is the log daily Canadian trading volume for the stock (divided by 100) obtained from Compustat. ALPHA_VOLUME is the log daily trading volume for a stock on Alpha (divided by 100). VOLATILITY is a 10-day moving average of the standard deviation of a stock's closing price obtained from Bloomberg. ALPHA_RELATIVE_SPREAD is the time-weighted average difference between the best bid and ask price divided by the midquote on Alpha (multiplied by 10,000). TSX_RELATIVE SPREAD is the time-weighted average difference between the best bid and ask price divided by the midquote on the Toronto Stock Exchange (TSX) (multiplied by 10,000). Firstdifference variables are denoted by $\Delta .{ }^{*},{ }^{* *}$, and ${ }^{* * *}$ indicate statistical significance at the $10 \%, 5 \%$, and $1 \%$ levels, respectively. $t$-statistics are given in parentheses. The marginal effect is reported below the $t$-statistic.
\end{abstract}

HFT Entry Events

\begin{tabular}{|c|c|c|c|}
\hline Variable & Daily & Weekly & Monthly \\
\hline CANADIAN_VOLUME & $\begin{array}{l}5.841^{\star \star \star} \\
(3.70) \\
0.097\end{array}$ & $\begin{array}{l}4.772^{\star \star} \\
(3.07) \\
0.289\end{array}$ & $\begin{array}{c}4.263 \\
(1.81) \\
0.732\end{array}$ \\
\hline ALPHA_VOLUME & $\begin{array}{c}1.424 \\
(1.15) \\
0.024\end{array}$ & $\begin{array}{c}0.718 \\
(0.63) \\
0.044\end{array}$ & $\begin{array}{c}0.689 \\
(0.41) \\
0.119\end{array}$ \\
\hline VOLATILITY & $\begin{array}{c}-2.134 \\
(-1.86) \\
-0.035\end{array}$ & $\begin{array}{c}0.368 \\
(0.30) \\
0.022\end{array}$ & $\begin{array}{l}5.301^{* *} \\
(2.73) \\
0.911\end{array}$ \\
\hline ALPHA_RELATIVE_SPREAD & $\begin{array}{c}0.751 \\
(1.27) \\
0.012\end{array}$ & $\begin{array}{c}-0.224 \\
(-0.33) \\
-0.014\end{array}$ & $\begin{array}{c}-0.301 \\
(-0.30) \\
-0.052\end{array}$ \\
\hline TSX_RELATIVE_SPREAD & $\begin{array}{c}-11.99^{\star \star \star} \\
(-4.82) \\
-0.199\end{array}$ & $\begin{array}{l}-18.04^{\star \star \star} \\
(-6.77) \\
-1.094\end{array}$ & $\begin{array}{c}-34.02 \\
(-7.61) \\
-5.847\end{array}$ \\
\hline$\triangle$ CANADIAN_VOLUME & $\begin{array}{c}-0.043 \\
(-0.02) \\
-0.001\end{array}$ & $\begin{array}{l}8.709^{\star *} \\
(2.42) \\
0.528\end{array}$ & $\begin{array}{c}9.086 \\
(1.48) \\
1.562\end{array}$ \\
\hline$\triangle \mathrm{ALPHA} V \mathrm{VOLUME}$ & $\begin{array}{c}3.448 \\
(1.42) \\
0.057\end{array}$ & $\begin{array}{r}-3.227 \\
(-1.05) \\
-0.196\end{array}$ & $\begin{array}{c}7.270 \\
(1.86) \\
1.250\end{array}$ \\
\hline$\triangle$ VOLATILITY & $\begin{array}{l}9.422^{\star \star} \\
(2.59) \\
0.157\end{array}$ & $\begin{array}{c}-2.323 \\
(-1.20) \\
-0.141\end{array}$ & $\begin{array}{l}-6.558^{\star *} \\
(-2.73) \\
-1.127\end{array}$ \\
\hline$\triangle$ ALPHA_RELATIVE_SPREAD & $\begin{array}{c}-1.079 \\
(-1.00) \\
-0.018\end{array}$ & $\begin{array}{c}-0.447 \\
(-0.40) \\
-0.027\end{array}$ & $\begin{array}{c}2.250 \\
(1.72) \\
0.387\end{array}$ \\
\hline$\triangle T S X \_R E L A T I V E \_S P R E A D$ & $\begin{array}{c}2.776 \\
(1.21) \\
0.046\end{array}$ & $\begin{array}{c}5.991 \\
(1.55) \\
0.363\end{array}$ & $\begin{array}{c}-0.953 \\
(-0.12) \\
-0.164\end{array}$ \\
\hline Constant & $\begin{array}{l}-3.315^{\star \star \star} \\
(-21.67)\end{array}$ & $\begin{array}{l}-2.480^{\star \star *} \\
(-15.80)\end{array}$ & $\begin{array}{l}-1.722^{\star \star *} \\
(-7.21)\end{array}$ \\
\hline $\begin{array}{l}\text { No. of obs. } \\
\text { Pseudo- } R^{2} \\
\text { No. of events }\end{array}$ & $\begin{array}{r}97,970 \\
0.019 \\
1,121\end{array}$ & $\begin{array}{r}36,204 \\
0.023 \\
1,121\end{array}$ & $\begin{array}{l}7,597 \\
0.044 \\
1,121\end{array}$ \\
\hline
\end{tabular}

to prove a negative. However, by ruling out likely sources of endogeneity, we make the set of alternatives more implausible. For a trend in an omitted variable to be consistent with our evidence, it would have to cause both HFT entry and a liquidity change during HFT entry; cause them via movements that bear a poor relation to levels and first differences in spreads, volume, and volatility at a daily, weekly, or monthly frequency; bear poor relation to the control variables in the DID model; and be present during a 4-year sample of 1,121 entry events over 279 stocks on Alpha. 


\section{Results of the DID Event Study on Market Liquidity}

In this section we present results on the change in market liquidity after a new HFT entrant begins trading a stock, by the number of HFT incumbents already in the stock, and for the first, second, and third months after entry. We use the DID event-study specification defined in Section II. We run the event study on three liquidity measures: EFFECTIVE_SPREAD_FOR_NON_HFT_TRADES, REALIZED_SPREAD_FOR_NON_HFT_TRADES, and PRICE_IMPACT_ FOR_NON_HFT_TRADES. We choose to measure effective and realized spreads because we are interested in realized trading costs, and we choose to measure liquidity for non-HFTs to ensure that the non-HFT clients of Alpha benefit. We choose to include the third measure of price impacts to check whether the change in the realized spread, which is partially a function of price impact, can be explained by changes in the price impact.

EFFECTIVE_SPREAD_FOR_NON_HFT_TRADES is twice the volumeweighted, signed difference between a trade's price and the prevailing midquote, in basis points, for aggressive trades not initiated by an HFT. It represents the transaction costs incurred by a non-HFT when trading aggressively. REALIZED_SPREAD_FOR_NON_HFT_TRADES is twice the volumeweighted, signed difference between a trade's price and the midquote in 5 seconds, in basis points from the prevailing midquote, for aggressive trades not initiated by an HFT. It is a proxy for market-maker profits net of price impact to providing liquidity to a non-HFT. Markets with lower effective spreads and lower realized spreads indicate greater realized liquidity. PRICE_IMPACT_FOR_NON_HFT_TRADES is the volume-weighted, signed difference between the midquote prevailing contemporaneous to a trade and the midquote in 5 seconds, in basis points from the original midquote, for aggressive trades not initiated by an HFT. Price impact represents the informational and inventory-bearing costs of a trade that are loaded on liquidity suppliers, and markets with lower price impact indicate fewer of these costs.

Figure 5 graphs the time series for the treatment and control stocks in a figure of parallel trends. This is useful to verify visually that the control stocks do not exhibit trends that distinguish them from the treatments.

The dotted lines in Figure 5 show the daily metric average, and the solid lines present the window average before and after the event. The black lines are for treated stocks, and the gray lines are for control stocks. The $x$-axis represents days relative to the event. The $y$-axis is the level of the spread in basis points. The graph of each average shows that there is virtually no change in the liquidity of the control stocks, whereas liquidity improves for the treatment stocks following entry.

Next, we present the event-study results. Tables 5-9 report impacts on spread metrics as the second, third, and fourth and later HFTs enter a market, and they report the impacts during the first, second, and third months after entry. Events for the second and third entrant are reported separately; events for the fourth or greater entrants are combined. In each of these tables, the immediate 1-month entry results are reported in Panel A, the second-month entry HFT coefficient is reported in Panel B, and the third-month entry HFT coefficient is reported in 
FIGURE 5

Parallel Trends

Figure 5 shows liquidity metrics for the treatment and control stocks, averaged daily over all treatments and controls during the 1 month before the high-frequency trader (HFT) entry dates and the 3 months after the entry dates. The dashed lines represent daily metrics, and the solid lines represent pre- and post-period averages. Treated stocks are in black, and control stocks are in gray. EFFECTIVE_SPREAD_FOR_NON_HFT_TRADES is twice the volume-weighted, signed difference between a trade's price and the prevailing midquote, in basis points, for aggressive trades not initiated by an HFT. REALIZED_SPREAD_FOR_NON_HFT_TRADES is twice the volume-weighted, signed difference between a trade's price and the midquote in 5 seconds, in basis points from the midquote, for aggressive trades not initiated by an HFT.
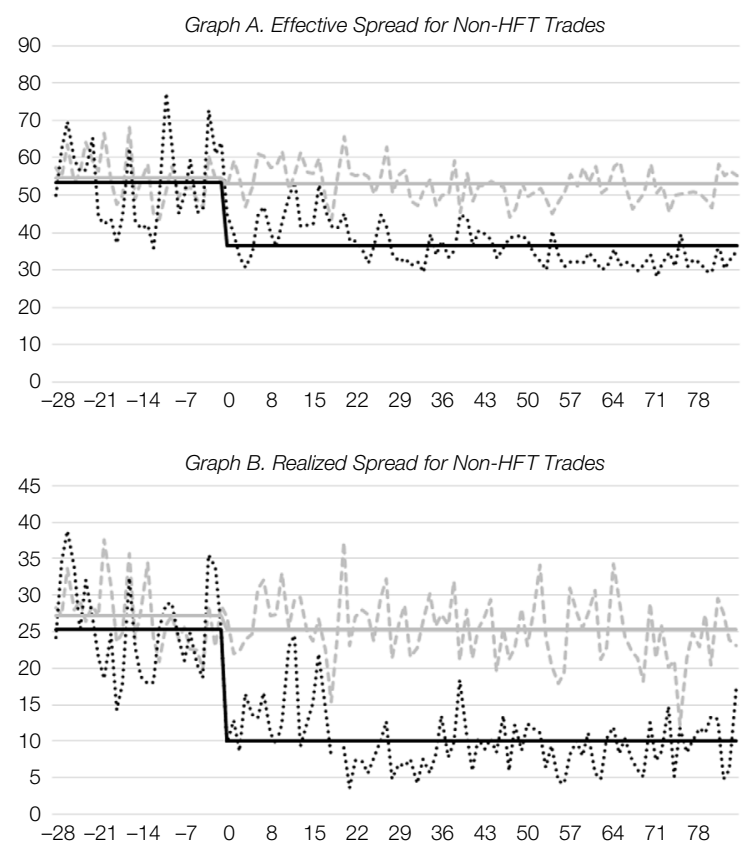

Panel C. The OLS results are given in columns 1-3 of each table, and the WLS results are given in columns 4-6.

Table 5 reports the estimated impact of passive HFT entry on non-HFT effective spreads.

So as to avoid redundant discussion, we discuss the OLS findings for this and all remaining tables. We note that the WLS results are economically similar. In fact, they are consistently stronger, which is consistent with (ex ante) larger HFT entries having a larger impact. Table 5 shows that a second HFT leads to tighter spreads by 38 bps during the first month after entry, and the third HFT does the same by 4 bps, both statistically significant. The second HFT has a longlived impact on liquidity: The effects retain their order and significance during the second and third months after entry. In every month, the impact is largest for the market with the fewest incumbents, and it is smallest for the market with the most incumbents. The fourth and later HFTs do not have a significant effect in any month, which is consistent with limits to price competition on an order book due to the minimum tick size. 
TABLE 5

Passive HFT Competition and Non-HFT Effective Spreads

Table 5 reports a difference-in-differences event study on non-high-frequency trader (HFT) effective spreads comparing the month before a stock-entry date of a passive HFT to the first, second, and third months after the date, run separately for the second, third, and fourth and later HFTs to begin trading. EFFECTIVE_SPREAD_FOR_NON_HFT_TRADES is twice the volume-weighted, signed difference between a trade's price and the prevailing midquote, in basis points, for aggressive trades not initiated by an HFT. A passive HFT is an HFT that uses predominantly limit orders to trade. For each treatment stock, a control is matched by Mahalanobis ranking on log market cap, log Toronto Stock Exchange (TSX) volume, price, 10-day price volatility, and absolute bid-ask spread during the month before the event. The regressors are HFT, the treatment dummy; AFTER, the post-period dummy; controls for log market cap (MARKET_CAP), log TSX volume (TSX_VOLUME), price (PRICE), 10-day price volatility (VOLATILITY), and number of traders (NUMBER_OF_FIRMS); and stock-event fixed effects. The event study is fit once using ordinary least squares (OLS) and once using weighted least squares (WLS), in which the weighting is the HFT entrant's volume share during the month. The immediate 1-month entry results are reported in Panel A, the second-month entry HFT coefficient is reported in Panel $\mathrm{B}$, and the third-month entry HFT coefficient is reported in Panel C. ${ }^{*},{ }^{* *}$, and ${ }^{* * *}$ indicate statistical significance at the $10 \%, 5 \%$, and $1 \%$ levels, respectively. $t$-statistics are given in parentheses. Standard errors are double-clustered by stock-event and calendar date.

\begin{tabular}{|c|c|c|c|c|c|c|}
\hline \multirow[b]{2}{*}{ Variable } & \multicolumn{3}{|c|}{ OLS } & \multicolumn{3}{|c|}{ WLS } \\
\hline & 2nd HFT & 3rd HFT & 4 th + & 2nd HFT & 3rd HFT & 4th + \\
\hline \multicolumn{7}{|c|}{ Panel A. Treatment Effect: Month 1} \\
\hline HFT & $\begin{array}{l}-38.39^{\star \star \star} \\
(-5.19)\end{array}$ & $\begin{array}{l}-4.49^{\star \star \star} \\
(-2.60)\end{array}$ & $\begin{array}{c}-0.83 \\
(-1.04)\end{array}$ & $\begin{array}{l}-53.54^{\star \star \star} \\
(-4.61)\end{array}$ & $\begin{array}{l}-6.27^{\star \star} \\
(-2.23)\end{array}$ & $\begin{array}{l}-0.24 \\
(-0.20)\end{array}$ \\
\hline AFTER & $\begin{array}{c}7.77 \\
(1.26)\end{array}$ & $\begin{array}{c}1.7 \\
(1.39)\end{array}$ & $\begin{array}{c}1.73^{\star \star} \\
(2.10)\end{array}$ & $\begin{array}{c}10.04 \\
(1.23)\end{array}$ & $\begin{array}{c}1.6 \\
(0.90)\end{array}$ & $\begin{array}{c}1.35 \\
(1.10)\end{array}$ \\
\hline MARKET_CAP & $\begin{array}{l}40.47 \\
(0.85)\end{array}$ & $\begin{array}{l}-37.94 \\
(-1.01)\end{array}$ & $\begin{array}{l}-19.53 \\
(-0.95)\end{array}$ & $\begin{array}{l}64.54 \\
(0.91)\end{array}$ & $\begin{array}{l}-19.46 \\
(-0.93)\end{array}$ & $\begin{array}{c}-11.93 \\
(-0.77)\end{array}$ \\
\hline TSX_VOLUME & $\begin{array}{c}2.56 \\
(0.69)\end{array}$ & $\begin{array}{l}-0.46 \\
(-0.64)\end{array}$ & $\begin{array}{l}-3.83^{\star \star \star} \\
(-2.90)\end{array}$ & $\begin{array}{c}4.02 \\
(0.82)\end{array}$ & $\begin{array}{l}-0.02 \\
(-0.02)\end{array}$ & $\begin{array}{l}-4.17^{* * *} \\
(-2.65)\end{array}$ \\
\hline PRICE & $\begin{array}{c}-0.56 \\
(-0.62)\end{array}$ & $\begin{array}{l}-0.63^{\star \star \star} \\
(-2.61)\end{array}$ & $\begin{array}{l}-0.24^{\star \star} \\
(-2.06)\end{array}$ & $\begin{array}{c}-1.55 \\
(-1.07)\end{array}$ & $\begin{array}{l}-0.63^{\star \star} \\
(-2.24)\end{array}$ & $\begin{array}{c}-0.19^{\star} \\
(-1.77)\end{array}$ \\
\hline VOLATILITY & $\begin{array}{l}-3.02^{\star \star} \\
(-2.10)\end{array}$ & $\begin{array}{c}1.38 \\
(1.58)\end{array}$ & $\begin{array}{l}1.37^{\star \star} \\
(2.31)\end{array}$ & $\begin{array}{l}-4.62^{\star \star} \\
(-2.01)\end{array}$ & $\begin{array}{c}1.21 \\
(1.05)\end{array}$ & $\begin{array}{l}1.80^{* *} \\
(2.42)\end{array}$ \\
\hline NUMBER_OF_FIRMS & $\begin{array}{l}-2.20^{\star \star \star} \\
(-4.21)\end{array}$ & $\begin{array}{l}-0.18 \\
(-1.39)\end{array}$ & $\begin{array}{c}0.06 \\
(0.99)\end{array}$ & $\begin{array}{l}-2.87^{\star \star \star} \\
(-4.21)\end{array}$ & $\begin{array}{c}-0.16 \\
(-0.70)\end{array}$ & $\begin{array}{c}-0.04 \\
(-0.32)\end{array}$ \\
\hline Fixed effects & Yes & Yes & Yes & Yes & Yes & Yes \\
\hline $\begin{array}{l}R^{2} \\
\text { No. of events }\end{array}$ & $\begin{array}{r}0.295 \\
140\end{array}$ & $\begin{array}{r}0.582 \\
122\end{array}$ & $\begin{array}{r}0.636 \\
298\end{array}$ & $\begin{array}{r}0.274 \\
140\end{array}$ & $\begin{array}{r}0.487 \\
122\end{array}$ & $\begin{array}{r}0.640 \\
298\end{array}$ \\
\hline \multicolumn{7}{|c|}{ Panel B. Treatment Effect: Month 2} \\
\hline HFT & $\begin{array}{l}-42.22^{\star \star \star} \\
(-3.85)\end{array}$ & $\begin{array}{l}-4.01^{*} \\
(-1.89)\end{array}$ & $\begin{array}{c}-1.02 \\
(-0.69)\end{array}$ & $\begin{array}{l}-59.44^{\star \star \star} \\
(-3.61)\end{array}$ & $\begin{array}{l}-5.39^{\star \star} \\
(-2.21)\end{array}$ & $\begin{array}{l}-0.13 \\
(-0.07)\end{array}$ \\
\hline \multicolumn{7}{|c|}{ Panel C. Treatment Effect: Month 3} \\
\hline HFT & $\begin{array}{l}-34.54^{\star \star \star} \\
(-4.06)\end{array}$ & $\begin{array}{l}-4.47 \\
(-1.45)\end{array}$ & $\begin{array}{l}-1.35 \\
(-1.20)\end{array}$ & $\begin{array}{l}-44.76^{\star \star \star} \\
(-3.30)\end{array}$ & $\begin{array}{l}-7.96^{\star} \\
(-1.89)\end{array}$ & $\begin{array}{c}0.36 \\
(0.21)\end{array}$ \\
\hline
\end{tabular}

Table 6 reports the estimated impact of aggressive HFT entry on non-HFT effective spreads.

Out of the 9 OLS specifications, only 3 give a statistically significant impact. For stocks with 3 or more incumbents, aggressive entry decreases the non-HFT effective spread by 2 bps in the second month and 4 bps in the third month; for stocks with 1 incumbent, aggressive entry improves it by $11 \mathrm{bps}$ in the second month. Our interpretation is that there is either no impact or perhaps a minor improvement in liquidity. Neither interpretation is consistent with aggressive HFT competition harming liquidity by trading only to adversely select market makers. The results are more consistent with aggressive HFTs pursuing many strategies that are on average neutral or slightly beneficial to the market. Aggressive HFTs may be competing to contribute to price efficiency, for example, by using news arbitrage or by monitoring market conditions. The results are consistent with 


\section{Aggressive HFT Competition and Non-HFT Effective Spreads}

Table 6 reports a difference-in-differences event study on non-high-frequency trader (HFT) effective spreads comparing the month before a stock-entry date of an aggressive HFT to the first, second, and third months after the date, run separately for the second, third, and fourth and later HFTs to begin trading. EFFECTIVE_SPREAD_FOR_NON_HFT_TRADES is twice the volume-weighted, signed difference between a trade's price and the prevailing midquote, in basis points, for aggressive trades not initiated by an HFT. An aggressive HFT is an HFT that uses predominantly marketable orders to trade. For each treatment stock, a control is matched by Mahalanobis ranking on log market cap, log Toronto Stock Exchange (TSX) volume, price, 10-day price volatility, and absolute bid-ask spread during the month before the event. The regressors are HFT, the treatment dummy; AFTER, the post-period dummy; controls for log market cap (MARKET CAP), log TSX volume (TSX_VOLUME), price (PRICE), 10-day price volatility (VOLATILITY), and number of traders (NUMBER_OF_FIRMS); and stock-event fixed effects. The event study is fit once using ordinary least squares (OLS) and once using weighted least squares (WLS), in which the weighting is the HFT entrant's volume share during the month. The immediate 1-month entry results are reported in Panel A, the second-month entry HFT coefficient is reported in Panel $\mathrm{B}$, and the third-month entry HFT coefficient is reported in Panel $\mathrm{C} .{ }^{*},{ }^{*}$, and ${ }^{* * *}$ indicate statistical significance at the $10 \%, 5 \%$, and $1 \%$ levels, respectively. $t$-statistics are given in parentheses. Standard errors are double-clustered by stock-event and calendar date.

\begin{tabular}{|c|c|c|c|c|c|c|}
\hline \multirow[b]{2}{*}{ Variable } & \multicolumn{3}{|c|}{ OLS } & \multicolumn{3}{|c|}{ WLS } \\
\hline & 2nd HFT & 3rd HFT & 4 th + & 2nd HFT & 3rd HFT & 4 th + \\
\hline \multicolumn{7}{|c|}{ Panel A. Treatment Effect: Month 1} \\
\hline HFT & $\begin{array}{l}-0.14 \\
(-0.05)\end{array}$ & $\begin{array}{c}1.83 \\
(1.05)\end{array}$ & $\begin{array}{l}-0.95 \\
(-1.15)\end{array}$ & $\begin{array}{c}2.15 \\
(0.29)\end{array}$ & $\begin{array}{c}2.55 \\
(1.18)\end{array}$ & $\begin{array}{l}-0.22 \\
(-0.21)\end{array}$ \\
\hline AFTER & $\begin{array}{l}0.6 \\
(0.22)\end{array}$ & $\begin{array}{l}-1.5 \\
(-1.00)\end{array}$ & $\begin{array}{l}2.20^{\star \star} \\
(2.43)\end{array}$ & $\begin{array}{c}3.33 \\
(0.84)\end{array}$ & $\begin{array}{c}-2.98^{*} \\
(-1.73)\end{array}$ & $\begin{array}{c}1.55 \\
(1.34)\end{array}$ \\
\hline MARKET_CAP & $\begin{array}{l}-5.62 \\
(-0.33)\end{array}$ & $\begin{array}{l}-87.56^{\star \star \star} \\
(-2.66)\end{array}$ & $\begin{array}{c}7.69 \\
(0.83)\end{array}$ & $\begin{array}{l}-20.04 \\
(-0.88)\end{array}$ & $\begin{array}{l}-90.36^{* * *} \\
(-3.04)\end{array}$ & $\begin{array}{l}-2.45 \\
(-0.17)\end{array}$ \\
\hline TSX_VOLUME & $\begin{array}{l}-1.17 \\
(-1.11)\end{array}$ & $\begin{array}{c}1.17 \\
(1.08)\end{array}$ & $\begin{array}{l}-1.76 \\
(-1.54)\end{array}$ & $\begin{array}{l}-1.57 \\
(-1.11)\end{array}$ & $\begin{array}{l}0.7 \\
(0.41)\end{array}$ & $\begin{array}{l}-2.27^{\text {** }} \\
(-1.97)\end{array}$ \\
\hline PRICE & $\begin{array}{r}(0.93) \\
(-0.62)\end{array}$ & $\begin{array}{l}(-1.70) \\
(-2.61)\end{array}$ & $\begin{array}{r}(0.15) \\
(-2.06)\end{array}$ & $\begin{array}{l}(-0.40) \\
(-1.07)\end{array}$ & $\begin{array}{l}(-1.08) \\
(-2.24)\end{array}$ & $\begin{array}{l}(-0.49) \\
(-1.77)\end{array}$ \\
\hline VOLATILITY & $\begin{array}{c}3.13 \\
(1.02)\end{array}$ & $\begin{array}{c}0.61 \\
(0.86)\end{array}$ & $\begin{array}{c}0.31 \\
(1.38)\end{array}$ & $\begin{array}{c}3.26 \\
(0.88)\end{array}$ & $\begin{array}{c}1.06 \\
(1.38)\end{array}$ & $\begin{array}{c}0.26 \\
(0.97)\end{array}$ \\
\hline NUMBER_OF_FIRMS & $\begin{array}{l}-0.75^{\star \star \star} \\
(-2.74)\end{array}$ & $\begin{array}{l}-0.16^{\star} \\
(-1.93)\end{array}$ & $\begin{array}{r}0.10^{*} \\
(1.73)\end{array}$ & $\begin{array}{l}-0.85^{\star * *} \\
(-2.70)\end{array}$ & $\begin{array}{l}-0.16 \\
(-1.34)\end{array}$ & $\begin{array}{c}0.13^{\text {** }} \\
(1.99)\end{array}$ \\
\hline Fixed effects & Yes & Yes & Yes & Yes & Yes & Yes \\
\hline $\begin{array}{l}R^{2} \\
\text { No. of events }\end{array}$ & $\begin{array}{c}0.303 \\
39\end{array}$ & $\begin{array}{c}0.451 \\
35\end{array}$ & $\begin{array}{r}0.682 \\
267\end{array}$ & $\begin{array}{c}0.261 \\
39\end{array}$ & $\begin{array}{c}0.408 \\
35\end{array}$ & $\begin{array}{r}0.667 \\
267\end{array}$ \\
\hline \multicolumn{7}{|c|}{ Panel B. Treatment Effect: Month 2} \\
\hline HFT & $\begin{array}{c}-11.29^{\star} \\
(-1.92)\end{array}$ & $\begin{array}{c}0.46 \\
(0.18)\end{array}$ & $\begin{array}{l}-2.33^{*} \\
(-1.96)\end{array}$ & $\begin{array}{c}-18.48^{*} \\
(-1.94)\end{array}$ & $\begin{array}{c}0.52 \\
(0.13)\end{array}$ & $\begin{array}{l}-2.29 \\
(-1.57)\end{array}$ \\
\hline \multicolumn{7}{|c|}{ Panel C. Treatment Effect: Month 3} \\
\hline HFT & $\begin{array}{c}-7.49 \\
(-1.48) \\
\end{array}$ & $\begin{array}{l}-3.56 \\
(-1.18) \\
\end{array}$ & $\begin{array}{l}-4.10^{\text {** }} \\
(-2.37)\end{array}$ & $\begin{array}{l}-7.95 \\
(-1.01)\end{array}$ & $\begin{array}{l}-5.76 \\
(-1.35) \\
\end{array}$ & $\begin{array}{r}-3.74^{*} \\
(-1.95) \\
\end{array}$ \\
\hline
\end{tabular}

those of Brogaard et al. (2014), who find that aggressive HFT trading contributes to price discovery. Because the results for aggressive HFT entry are nearly all statistically insignificant, we report them in the Supplementary Material and focus on the passive HFT entries for the remainder of the article.

Table 7 reports the estimated impact of passive HFT entry on non-HFT realized spreads.

For the first month after entry, the second HFT leads to tighter spreads by $27 \mathrm{bps}$, and the third HFT by 5 bps. Both results are statistically significant. The second HFT has a long-lived impact on liquidity: The effects retain their order and significance during the second and third months after entry. In each month, the impact is largest for the market with the fewest incumbents and smallest for the market with the most incumbents. The fourth and later HFTs do not have a 
TABLE 7

Passive HFT Competition and Non-HFT Realized Spreads

Table 7 reports a difference-in-differences event study on non-high-frequency trader (HFT) effective spreads comparing the month before a stock-entry date of a passive HFT to the first, second, and third months after the date, run separately for the second, third, and fourth and later HFTs to begin trading. REALIZED_SPREAD_FOR_NON_HFT_TRADES is twice the volume-weighted, signed difference between a trade's price and the midquote in 5 seconds, in basis points from the midquote, for aggressive trades not initiated by an HFT. A passive HFT is an HFT that uses predominantly limit orders to trade. For each treatment stock, a control is matched by Mahalanobis ranking on log market cap, log Toronto Stock Exchange (TSX) volume, price, 10-day price volatility, and absolute bid-ask spread during the month before the event. The regressors are HFT, the treatment dummy; AFTER, the post-period dummy; controls for log market cap (MARKET CAP), log TSX volume (TSX_VOLUME), price (PRICE), 10-day price volatility (VOLATILITY), and number of traders (NUMBER_OF_FIRMS); and stock-event fixed effects. The event study is fit once using ordinary least squares (OLS) and once using weighted least squares (WLS), in which the weighting is the HFT entrant's volume share during the month. The immediate 1-month entry results are reported in Panel A, the second-month entry HFT coefficient is reported in Panel $\mathrm{B}$, and the third-month entry HFT coefficient is reported in Panel $\mathrm{C} .{ }^{*},{ }^{*}$, and ${ }^{* * *}$ indicate statistical significance at the $10 \%, 5 \%$, and $1 \%$ levels, respectively. $t$-statistics are given in parentheses. Standard errors are double-clustered by stock-event and calendar date.

\begin{tabular}{|c|c|c|c|c|c|c|}
\hline \multirow[b]{2}{*}{ Variable } & \multicolumn{3}{|c|}{ OLS } & \multicolumn{3}{|c|}{ WLS } \\
\hline & 2nd HFT & 3rd HFT & 4th + & 2nd HFT & 3rd HFT & 4 th + \\
\hline \multicolumn{7}{|c|}{ Panel A. Treatment Effect: Month 1} \\
\hline HFT & $\begin{array}{l}-26.62^{\star \star \star} \\
(-4.61)\end{array}$ & $\begin{array}{l}-5.16^{\star *} \\
(-2.11)\end{array}$ & $\begin{array}{c}0.02 \\
(0.02)\end{array}$ & $\begin{array}{l}-36.20^{\star \star \star} \\
(-4.44)\end{array}$ & $\begin{array}{l}-7.58^{\star} \\
(-1.81)\end{array}$ & $\begin{array}{l}-0.22 \\
(-0.19)\end{array}$ \\
\hline AFTER & $\begin{array}{c}5.07 \\
(0.94)\end{array}$ & $\begin{array}{c}3.86 \\
(1.50)\end{array}$ & $\begin{array}{r}1.69^{*} \\
(1.90)\end{array}$ & $\begin{array}{l}5.7 \\
(0.79)\end{array}$ & $\begin{array}{c}6.49 \\
(1.48)\end{array}$ & $\begin{array}{l}2.49^{* *} \\
(2.01)\end{array}$ \\
\hline MARKET_CAP & $\begin{array}{l}21.73 \\
(0.70)\end{array}$ & $\begin{array}{l}-34.35 \\
(-1.21)\end{array}$ & $\begin{array}{l}-11.18 \\
(-0.54)\end{array}$ & $\begin{array}{l}38.11 \\
(0.79)\end{array}$ & $\begin{array}{l}-38.14 \\
(-1.47)\end{array}$ & $\begin{array}{l}-5.4 \\
(-0.32)\end{array}$ \\
\hline TSX_VOLUME & $\begin{array}{l}-2.12 \\
(-0.55)\end{array}$ & $\begin{array}{l}-3.83^{\star \star \star} \\
(-3.56)\end{array}$ & $\begin{array}{l}-7.13^{\star \star \star} \\
(-4.93)\end{array}$ & $\begin{array}{l}-1.41 \\
(-0.29)\end{array}$ & $\begin{array}{l}-4.49^{\star \star} \\
(-2.57)\end{array}$ & $\begin{array}{l}-7.16^{\text {***}} \\
(-4.50)\end{array}$ \\
\hline PRICE & $\begin{array}{l}-0.74 \\
(-0.98)\end{array}$ & $\begin{array}{l}-0.49^{\star} \\
(-1.76)\end{array}$ & $\begin{array}{l}-0.1 \\
(-0.82)\end{array}$ & $\begin{array}{l}-1.52 \\
(-1.31)\end{array}$ & $\begin{array}{l}-0.45 \\
(-1.20)\end{array}$ & $\begin{array}{l}-0.03 \\
(-0.30)\end{array}$ \\
\hline VOLATILITY & $\begin{array}{l}-2.59^{*} \\
(-1.90)\end{array}$ & $\begin{array}{c}0.25 \\
(0.14)\end{array}$ & $\begin{array}{l}1.11^{\star \star} \\
(2.32)\end{array}$ & $\begin{array}{l}-3.83^{*} \\
(-1.74)\end{array}$ & $\begin{array}{c}0.62 \\
(0.24)\end{array}$ & $\begin{array}{l}1.49^{\star *} \\
(2.48)\end{array}$ \\
\hline NUMBER_OF_FIRMS & $\begin{array}{l}-1.21^{\star \star} \\
(-2.56)\end{array}$ & $\begin{array}{l}-0.01 \\
(-0.05)\end{array}$ & $\begin{array}{c}0.09 \\
(1.10)\end{array}$ & $\begin{array}{l}-1.64^{\star \star} \\
(-2.57)\end{array}$ & $\begin{array}{c}0.26 \\
(0.66)\end{array}$ & $\begin{array}{c}0.05 \\
(0.63)\end{array}$ \\
\hline Fixed effects & Yes & Yes & Yes & Yes & Yes & Yes \\
\hline $\begin{array}{l}R^{2} \\
\text { No. of events }\end{array}$ & $\begin{array}{r}0.165 \\
140\end{array}$ & $\begin{array}{l}0.18 \\
122\end{array}$ & $\begin{array}{r}0.404 \\
298\end{array}$ & $\begin{array}{r}0.146 \\
140\end{array}$ & $\begin{array}{r}0.108 \\
122\end{array}$ & $\begin{array}{r}0.402 \\
298\end{array}$ \\
\hline \multicolumn{7}{|c|}{ Panel B. Treatment Effect: Month 2} \\
\hline HFT & $\begin{array}{l}-32.99^{\star \star \star} \\
(-3.78)\end{array}$ & $\begin{array}{l}-3.88^{\star \star} \\
(-2.03)\end{array}$ & $\begin{array}{c}0.85 \\
(0.67)\end{array}$ & $\begin{array}{l}-44.47^{\star \star \star} \\
(-3.62)\end{array}$ & $\begin{array}{l}-3.91^{\star} \\
(-1.70)\end{array}$ & $\begin{array}{c}1.61 \\
(1.01)\end{array}$ \\
\hline \multicolumn{7}{|c|}{ Panel C. Treatment Effect: Month 3} \\
\hline HFT & $\begin{array}{l}-23.22^{\star \star \star} \\
(-3.79)\end{array}$ & $\begin{array}{l}-4.38 \\
(-1.22)\end{array}$ & $\begin{array}{c}0.1 \\
(0.08)\end{array}$ & $\begin{array}{l}-27.35^{\star \star \star} \\
(-3.09)\end{array}$ & $\begin{array}{l}-7.5 \\
(-1.32) \\
\end{array}$ & $\begin{array}{c}2.31 \\
(1.17)\end{array}$ \\
\hline
\end{tabular}

significant effect in any month, which is consistent with limits to price competition on an order book due to the minimum tick size. ${ }^{5}$

One circumstance that could confound the result in Table 7 is if price impacts are increasing contemporaneous to HFT entry. The realized spread is composed of the effective spread minus the price impact, so it is possible that the observed decrease in realized spreads could derive from a contemporaneous increase in price impacts. Such an increase in price impacts could be the result of an increase in the informational content of trading on Alpha that is unrelated to HFTs, or it could even be due to HFTs. To check for the possibility, we estimate the change in price impacts around HFT entry events.

\footnotetext{
${ }^{5}$ Another measure of liquidity we can evaluate is the quoted spread. We report the quoted spread results in the Supplementary Material. They are qualitatively similar to the effective and realized spreads.
} 
Passive HFT Competition and Non-HFT Price Impacts

Table 8 reports a difference-in-differences event study on non-high-frequency trader (HFT) price impacts comparing the month before a stock-entry date of a passive HFT to the first, second, and third months after the date, run separately for the second, third, and fourth and later HFTs to begin trading. PRICE_IMPACT_OF_NON_HFT_TRADES is the volume-weighted, signed difference between the midquote prevailing contemporaneous to a trade and the midquote in 5 seconds, in basis points from the original midquote, for aggressive trades not initiated by an HFT. A passive HFT is an HFT that uses predominantly limit orders to trade. For each treatment stock, a control is matched by Mahalanobis ranking on log market cap, log Toronto Stock Exchange (TSX) volume, price, 10-day price volatility, and absolute bidask spread during the month before the event. The regressors are HFT, the treatment dummy; AFTER, the post-period dummy; controls for log market cap (MARKET_CAP), log TSX volume (TSX_VOLUME), price (PRICE), 10-day price volatility (VOLATILITY), and number of traders (NUMBER_OF_FIRMS); and stock-event fixed effects. The event study is fit once using ordinary least squares (OLS) and once using weighted-least squares (WLS), in which the weighting is the HFT entrant's volume share during the month. The immediate 1-month entry results are reported in Panel A, the second-month entry HFT coefficient is reported in Panel B, and the third-month entry HFT coefficient is reported in Panel C. ${ }^{*},{ }^{* *}$, and ${ }_{* * *}$ indicate statistical significance at the $10 \%, 5 \%$, and $1 \%$ levels, respectively. $t$-statistics are given in parentheses. Standard errors are double-clustered by stock-event and calendar date.

\begin{tabular}{|c|c|c|c|c|c|c|}
\hline \multirow[b]{2}{*}{ Variable } & \multicolumn{3}{|c|}{ OLS } & \multicolumn{3}{|c|}{ WLS } \\
\hline & 2nd HFT & 3rd HFT & 4 th + & 2nd HFT & 3rd HFT & 4 th + \\
\hline \multicolumn{7}{|c|}{ Panel A. Treatment Effect: Month 1} \\
\hline HFT & $\begin{array}{l}-10.03^{* *} \\
(-2.18)\end{array}$ & $\begin{array}{c}0.31 \\
(0.11)\end{array}$ & $\begin{array}{l}-0.83 \\
(-1.09)\end{array}$ & $\begin{array}{l}-15.09^{\star \star} \\
(-2.01)\end{array}$ & $\begin{array}{c}0.13 \\
(0.03)\end{array}$ & $\begin{array}{l}-0.01 \\
(-0.01)\end{array}$ \\
\hline AFTER & $\begin{array}{c}1.40 \\
(0.44)\end{array}$ & $\begin{array}{l}-0.96 \\
(-0.54)\end{array}$ & $\begin{array}{c}0.15 \\
(0.18)\end{array}$ & $\begin{array}{c}2.42 \\
(0.60)\end{array}$ & $\begin{array}{l}-2.54 \\
(-0.83)\end{array}$ & $\begin{array}{l}-0.84 \\
(-0.68)\end{array}$ \\
\hline MARKET_CAP & $\begin{array}{l}37.52 \\
(1.20)\end{array}$ & $\begin{array}{l}-7.53 \\
(-0.36)\end{array}$ & $\begin{array}{l}-15.75 \\
(-1.22)\end{array}$ & $\begin{array}{l}56.95 \\
(1.30)\end{array}$ & $\begin{array}{c}8.43 \\
(0.37)\end{array}$ & $\begin{array}{l}-17.03 \\
(-1.05)\end{array}$ \\
\hline TSX_VOLUME & $\begin{array}{c}3.32^{\star} \\
(1.71)\end{array}$ & $\begin{array}{c}2.12^{*} \\
(1.70)\end{array}$ & $\begin{array}{l}4.46^{\star \star \star} \\
(4.46)\end{array}$ & $\begin{array}{c}3.25 \\
(1.04)\end{array}$ & $\begin{array}{c}2.49 \\
(1.20)\end{array}$ & $\begin{array}{l}4.34^{* * *} \\
(4.31)\end{array}$ \\
\hline PRICE & $\begin{array}{c}0.15 \\
(0.32)\end{array}$ & $\begin{array}{l}-0.25 \\
(-1.14)\end{array}$ & $\begin{array}{l}-0.27^{\star \star \star} \\
(-2.85)\end{array}$ & $\begin{array}{c}0.17 \\
(0.23)\end{array}$ & $\begin{array}{l}-0.21 \\
(-0.71)\end{array}$ & $\begin{array}{l}-0.28^{* *} \\
(-2.47)\end{array}$ \\
\hline VOLATILITY & $\begin{array}{l}-0.37 \\
(-0.42)\end{array}$ & $\begin{array}{l}2.18^{* *} \\
(2.38)\end{array}$ & $\begin{array}{l}-0.11 \\
(-0.39)\end{array}$ & $\begin{array}{l}-0.84 \\
(-0.70)\end{array}$ & $\begin{array}{l}2.14^{*} \\
(1.76)\end{array}$ & $\begin{array}{l}-0.13 \\
(-0.31)\end{array}$ \\
\hline NUMBER_OF_FIRMS & $\begin{array}{l}-0.82^{* \star \star} \\
(-3.56)\end{array}$ & $\begin{array}{l}-0.10 \\
(-0.54)\end{array}$ & $\begin{array}{l}-0.11 \\
(-1.57)\end{array}$ & $\begin{array}{l}-0.95^{\star \star \star} \\
(-3.03)\end{array}$ & $\begin{array}{l}-0.23 \\
(-0.65)\end{array}$ & $\begin{array}{l}-0.20^{*} \\
(-1.66)\end{array}$ \\
\hline Fixed effects & Yes & Yes & Yes & Yes & Yes & Yes \\
\hline $\begin{array}{l}R^{2} \\
\text { No. of events }\end{array}$ & $\begin{array}{r}0.156 \\
140\end{array}$ & $\begin{array}{r}0.161 \\
122\end{array}$ & $\begin{array}{r}0.287 \\
298\end{array}$ & $\begin{array}{r}0.165 \\
140\end{array}$ & $\begin{array}{r}0.139 \\
122\end{array}$ & $\begin{array}{r}0.275 \\
298\end{array}$ \\
\hline \multicolumn{7}{|c|}{ Panel B. Treatment Effect: Month 2} \\
\hline HFT & $\begin{array}{l}-7.25 \\
(-1.29)\end{array}$ & $\begin{array}{l}-2.17 \\
(-0.96)\end{array}$ & $\begin{array}{l}-1.40 \\
(-1.15)\end{array}$ & $\begin{array}{l}-10.91 \\
(-1.23)\end{array}$ & $\begin{array}{l}-5.53 \\
(-1.46)\end{array}$ & $\begin{array}{l}-1.52 \\
(-0.81)\end{array}$ \\
\hline \multicolumn{7}{|c|}{ Panel C. Treatment Effect: Month 3} \\
\hline HFT & $\begin{array}{l}-13.30^{* *} \\
(-2.20)\end{array}$ & $\begin{array}{l}-2.43 \\
(-1.17)\end{array}$ & $\begin{array}{l}-2.05 \\
(-1.52)\end{array}$ & $\begin{array}{l}-17.09^{\star} \\
(-1.88)\end{array}$ & $\begin{array}{c}-4.91 \\
(-1.53)\end{array}$ & $\begin{array}{l}-4.02 \\
(-1.46)\end{array}$ \\
\hline
\end{tabular}

In Table 8, we fail to find much evidence of a change in price impacts. There are only two statistically significant effects, and rather than increases, they are both decreases: Price impacts decrease after the second entrant by 10 bps in the first month and by 13 bps in the third month. The evidence is consistent with the decline in realized spreads being driven by lower spreads, not by larger price impacts on Alpha. The observed decreases in price impacts can be explained by the known tendency for HFTs to trade against price movements, as noted by Brogaard et al. (2014).

Table 9 reports the estimated impact of passive HFT entry on the inside depth.

Unlike the spread measures, the depth results are nearly all statistically significantly no different from 0 . These results suggest that the effect of competition 
TABLE 9

Passive HFT Competition and Inside Depth

Table 9 reports a difference-in-differences event study on inside depth comparing the month before a stock-entry date of a passive high-frequency trader (HFT) to the first, second, and third months after the date, run separately for the second, third, and fourth and later HFTs to begin trading. INSIDE_DEPTH is the sum of the quantity of limit orders outstanding at the best bid and ask prices. A passive HFT is an HFT that uses predominantly limit orders to trade. For each treatment stock, a control is matched by Mahalanobis ranking on log market cap, log Toronto Stock Exchange (TSX) volume, price, 10-day price volatility, and absolute bid-ask spread during the month before the event. The regressors are HFT, the treatment dummy; AFTER, the post-period dummy; controls for log market cap (MARKET_CAP), log TSX volume (TSX_VOLUME), price (PRICE), 10-day price volatility (VOLATILITY), and number of traders (NUMBER_OF_FIRMS); and stock-event fixed effects. The event study is fit once using ordinary least squares (OLS) and once using weighted least squares (WLS), in which the weighting is the HFT entrant's volume share during the month. The immediate 1-month entry results are reported in Panel A, the second-month entry HFT coefficient is reported in Panel B, and the third-month entry HFT coefficient is reported in Panel C. ${ }^{*}{ }^{* *}$, and ${ }^{* * *}$ indicate statistical significance at the $10 \%, 5 \%$, and $1 \%$ levels, respectively. $t$-statistics are given in parentheses. Standard errors are double-clustered by stock-event and calendar date.

\begin{tabular}{|c|c|c|c|c|c|c|}
\hline \multirow[b]{2}{*}{ Variable } & \multicolumn{3}{|c|}{ OLS } & \multicolumn{3}{|c|}{ WLS } \\
\hline & 2nd HFT & 3rd HFT & 4 th + & 2nd HFT & 3rd HFT & 4 th + \\
\hline \multicolumn{7}{|c|}{ Panel A. Treatment Effect: Month 1} \\
\hline HFT & $\begin{array}{r}1,958.67 \\
(1.49)\end{array}$ & $\begin{array}{r}-1,066.41 \\
(-0.61)\end{array}$ & $\begin{array}{r}1,393.02 \\
(1.16)\end{array}$ & $\begin{array}{r}1,028.23 \\
(1.46)\end{array}$ & $\begin{array}{l}40 \\
(0.06)\end{array}$ & $\begin{array}{r}840.55 \\
(1.04)\end{array}$ \\
\hline AFTER & $\begin{array}{c}781.51 \\
(1.13)\end{array}$ & $\begin{array}{r}-835.27 \\
(-0.94)\end{array}$ & $\begin{array}{r}682.95 \\
(0.87)\end{array}$ & $\begin{array}{r}492.91 \\
(0.93)\end{array}$ & $\begin{array}{c}-509.01 \\
(-1.14)\end{array}$ & $\begin{array}{c}1,167.07^{* *} \\
(2.05)\end{array}$ \\
\hline MARKET_CAP & $\begin{array}{r}1,354.63 \\
(0.35)\end{array}$ & $\begin{array}{l}4,981.1 \\
(0.52)\end{array}$ & $\begin{array}{r}2,988.86 \\
(0.14)\end{array}$ & $\begin{array}{r}310.33 \\
(0.09)\end{array}$ & $\begin{array}{r}2,768.64 \\
(0.32)\end{array}$ & $\begin{array}{r}-4,232.02 \\
(-0.22)\end{array}$ \\
\hline TSX_VOLUME & $\begin{array}{c}1,160.30^{\star \star \star} \\
(2.88)\end{array}$ & $\begin{array}{c}1,948.67^{\star \star \star} \\
(4.28)\end{array}$ & $\begin{array}{c}2,963.25^{\star \star \star} \\
(8.07)\end{array}$ & $\begin{array}{c}1,059.66^{\star \star \star} \\
(2.89)\end{array}$ & $\begin{array}{c}1,252.84^{\star \star \star} \\
(4.74)\end{array}$ & $\begin{array}{c}2,380.02^{* * *} \\
(7.09)\end{array}$ \\
\hline PRICE & $\begin{array}{l}204.7 \\
(1.29)\end{array}$ & $\begin{array}{r}-132.48 \\
(-0.30)\end{array}$ & $\begin{array}{c}137.05 \\
(0.79)\end{array}$ & $\begin{array}{r}223.79^{*} \\
(1.77)\end{array}$ & $\begin{array}{l}32.25 \\
(0.24)\end{array}$ & $\begin{array}{l}59.22 \\
(0.62)\end{array}$ \\
\hline VOLATILITY & $\begin{array}{l}64.57 \\
(0.16)\end{array}$ & 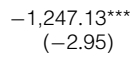 & $\begin{array}{c}434.79 \\
(1.45)\end{array}$ & $\begin{array}{c}158.42 \\
(0.60)\end{array}$ & 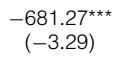 & $\begin{array}{r}209.23 \\
(0.83)\end{array}$ \\
\hline NUMBER_OF_FIRMS & $\begin{array}{c}232.16^{\star \star \star} \\
(3.70)\end{array}$ & $\begin{array}{c}47.95 \\
(0.67)\end{array}$ & $\begin{array}{l}-15.43 \\
(-0.25)\end{array}$ & $\begin{array}{c}238.16^{\star \star *} \\
(4.26)\end{array}$ & $\begin{array}{l}64.61^{*} \\
(1.80)\end{array}$ & $\begin{array}{c}31.19 \\
(0.60)\end{array}$ \\
\hline Fixed effects & Yes & Yes & Yes & Yes & Yes & Yes \\
\hline $\begin{array}{l}R^{2} \\
\text { No. of events }\end{array}$ & $\begin{array}{l}0.81 \\
140\end{array}$ & $\begin{array}{r}0.842 \\
122\end{array}$ & $\begin{array}{r}0.861 \\
298\end{array}$ & $\begin{array}{r}0.798 \\
140\end{array}$ & $\begin{array}{r}0.838 \\
122\end{array}$ & $\begin{array}{r}0.844 \\
298\end{array}$ \\
\hline \multicolumn{7}{|c|}{ Panel B. Treatment Effect: Month 2} \\
\hline HFT & $\begin{array}{r}4,143.81^{*} \\
(1.77)\end{array}$ & $\begin{array}{r}1,133.56 \\
(0.54)\end{array}$ & $\begin{array}{r}-150.12 \\
(-0.14)\end{array}$ & $\begin{array}{r}2,095.66 \\
(1.18)\end{array}$ & $\begin{array}{r}831.35 \\
(0.81)\end{array}$ & $\begin{array}{l}16.63 \\
(0.02)\end{array}$ \\
\hline \multicolumn{7}{|c|}{ Panel C. Treatment Effect: Month 3} \\
\hline HFT & $\begin{array}{r}3,191.03 \\
(1.22) \\
\end{array}$ & $\begin{array}{r}2,177.86 \\
(1.39) \\
\end{array}$ & $\begin{array}{c}393.82 \\
(0.34) \\
\end{array}$ & $\begin{array}{c}166.92 \\
(0.11) \\
\end{array}$ & $\begin{array}{r}1,336.19 \\
(1.26) \\
\end{array}$ & $\begin{array}{c}882.9 \\
(1.05)\end{array}$ \\
\hline
\end{tabular}

among HFTs on the Alpha exchange is on the bid-ask spread, not on the number of shares available.

In summary, Section III shows that HFT competition improves liquidity. If HFT competition did not benefit liquidity, one would expect that the entrance of a second or third passive HFT would have no effect on spreads. However, we find that the second and third passive HFTs do improve spreads. Moreover, we find that the impact of competition is long-lived, that the relationship is strongest when there are fewer incumbents, and that the effect diminishes as the number of incumbents grows, consistent with intuition about diminishing returns to competition. In general, the result is consistent with non-HFTs benefiting by accessing the lower spreads induced by HFT competition. 


\section{Is HFT Competition Consistent with Price or Quantity Competition?}

In the previous section, we presented evidence that HFT competition on Alpha improves liquidity. In this section, we give an explanation for why. We argue that it is because HFT competition is a form of quantity competition, an industrial organization that is characteristic of many markets (Bresnahan (1989)). ${ }^{6}$ Under quantity competition, firms use their market power to raise prices, but competition can erode their market power. Many microstructure models use a basis of quantity competition (e.g., Kyle (1989), Subrahmanyam (1991), Biais et al. (2000), and Bondarenko (2001)). Although these models were not written with HFTs specifically in mind, we see this as an advantage. The consistency of the data suggests it can be useful to model HFTs with the assumptions found in these traditional models.

In recent theory, HFT competition instead is assumed to be price competition (Budish et al. (2015), Menkveld and Zoican (2017)). Under price competition, firms lack market power, so they bid prices down to marginal cost. Price competition is a tractable assumption for theorists because it fixes the quantity output. However, because firms have no market power, price competition has the strong consequence that increased competition among similar firms brings no benefit (although it can still have costs). Although we cannot test for price competition directly because we lack data on the firms' marginal costs, we can show that the Alpha market responds to firm entry in ways that are difficult to explain via price competition but that are natural outcomes of quantity competition.

Specifically, we draw three hypotheses inspired by Kyle (1989) that are also identical to the predictions of the Cournot model, the classic model of quantity competition, with the standard features of linear cost, linear demand, and identical firms. ${ }^{7}$ As the number of firms $N$ increases:

1. Market size: Total volume increases in $N /(N+1)$.

2. Market share: The volume of incumbents decreases in $1 / N$.

3. Liquidity: The price of liquidity decreases in $1 / N$.

These predictions, particularly the first, are implausible in a model that assumes price competition. The first is implausible because in price competition, the quantity output is fixed. The second and third are also difficult for price competition because under that assumption, only the firms with the lowest marginal cost produce. However, for predictions 2 and 3, it is possible that strictly costimproving firms could progressively enter Alpha in increasing numbers, which could generate the same observable consequences. We cannot test this because we lack data on firms' marginal costs.

To demonstrate robustness, we also study how the magnitude of each result changes in the number of firms. We find that the magnitude of the results on

\footnotetext{
${ }^{6}$ For more on the role of competition in industrial organization, see Tirole (1988).

${ }^{7}$ Prediction 3 is equation (40) of Kyle (1989). Prediction 2 draws from equation (44) of Kyle (1989), in which the residual supply curves attenuate in the number of like participants, and prediction 1 is the same equation summed over the $N$ participants.
} 
volume, incumbent volume, and liquidity all attenuate in the number of firms $N$. This is consistent with our interpretation that the HFT environment is characterized by quantity competition because a diminishing return in the number of firms $N$ is also implausible in a model with price competition.

To test the hypotheses, we compute one data series for each of the three predictions and run the event study on the variable. For the first prediction, we compute the volume share of all HFTs as a proportion of total volume. For the second, we compute the volume share of only the HFT incumbents as a proportion of total volume. For the third, we compute the effective spreads of trades on which an HFT incumbent was the passive counterparty. We estimate the treatment effects on these three variables using the same DID event-study methodology described in Section II. In Tables 10-12, the events for the second and third entrants are reported in separate columns, and the events for the fourth or greater entrant are combined. In each table, the immediate 1-month entry results are reported in Panel A, the second-month entry HFT coefficient is reported in Panel B, and the thirdmonth entry HFT coefficient is reported in Panel C. The OLS results are given in columns $1-3$, and the WLS results are given in columns 4-6.

\section{A. Market Share of the Industry and of Incumbents}

To test the predictions of quantity competition on total output and incumbent output, we compute the volume shares of HFTs trading Alpha stocks. HFT_VOLUME_SHARE is the percentage of trading volume (HFT shares traded/ $(2 \times$ total shares traded $))$ executed by HFTs for stock $i$ on day $t$. HFT_INCUMBENT_VOLUME_SHARE is the percentage of trading volume (incumbent HFT shares traded/ $(2 \times$ total shares traded $)$ ) executed by incumbent HFTs (i.e., all HFTs except the entrant) for stock $i$ on day $t$. The treatment coefficient is the percentage-point change in HFT activity in stock $i$ following a new HFT entry.

Table 10 reports the results of the DID event study on the volume share of the HFT industry.

Consistent with quantity competition, HFT entry increases the HFT share of volumes. After the second HFT arrives, the impact is largest: 5 percentage points. The impact of entry lasts throughout the event window of 3 months and retains its magnitude. As with the 1-month results, the largest impact in the third month is after the second HFT arrives, still at 5 percentage points. Consistent with quantity competition, there are diminishing returns in the number of firms. The entry impact is smallest after the fourth or later entrant, at 2 percentage points. In each of the 3 months, we study the impact of decreases in the number of HFT incumbents. The results on volume share are some of the most statistically significant in our study; quantity competition holds even in the case of 4 or more HFTs.

Table 11 reports the results of the DID event study on the volume share of incumbent HFTs only.

HFT entry has the reverse effect on incumbent volume share as it does on total volume share. Consistent with quantity competition, entry decreases incumbent volumes. In the first month, the second HFT to arrive takes 5 percentage points of volume share from incumbents. As before, the impact of entry for the second entrant is long-lived, being statistically significant in each month of the 
event study. In the third month, the second HFT to arrive takes 6 percentage points from incumbents. The impacts decline in the number of HFT incumbents. The second entrant is more successful in capturing market share than the third entrant, and the third entrant is more successful than the fourth and later entrants. The third and higher entrants do not exhibit statistical significance after the first month.

Overall, the results on volume shares are consistent with an increasing competitiveness of HFTs in markets with more firms. Based on Tables 10 and 11, HFT entry tends to increase total HFT volumes and at a decreasing rate. HFT entry seizes trading volume from incumbents, again at a decreasing rate. Output increases more in markets with few HFTs; losses to incumbents are larger for stocks with few HFTs. The results and their diminishing returns are consistent with quantity competition because in quantity competition, firms produce different amounts of quantity depending on the industrial organization. They are not consistent with price competition, in which output does not increase in the number of firms.

\section{TABLE 10}

HFT Competition and HFTs' Share of Volume

Table 10 reports a difference-in-differences event study on the volume share of high-frequency traders (HFTs) comparing the month before a stock-entry date of an HFT to the first, second, and third months after the date, run separately for the second, third, and fourth and later HFTs to begin trade. HFT_VOLUME_SHARE is the percentage of daily volume for which an HFT is one counterparty. For each treatment stock, a control is matched by Mahalanobis ranking on log market cap, log Toronto Stock Exchange (TSX) volume, price, 10-day price volatility, and absolute bid-ask spread during the month before the event. The regressors are HFT, the treatment dummy; AFTER, the post-period dummy; controls for log market cap (MARKET_CAP), log TSX volume (TSX_VOLUME), price (PRICE), 10-day price volatility (VOLATILITY), and number of traders (NUMBER_OF_FIRMS); and stock-event fixed effects. The event study is fit once using ordinary least squares (OLS) and once using weighted least squares (WLS), in which the weighting is the HFT entrant's volume share during the month. The immediate 1-month entry results are reported in Panel A, the second-month entry HFT coefficient is reported in Panel B, and the third-month entry HFT coefficient is reported in Panel C. ${ }^{*}$, ${ }^{* *}$, and ${ }^{* * *}$ indicate statistical significance at the $10 \%, 5 \%$, and $1 \%$ levels, respectively. $t$-statistics are given in parentheses. Standard errors are double-clustered by stock-event and calendar date.

\begin{tabular}{|c|c|c|c|c|c|c|}
\hline \multirow[b]{2}{*}{ Variable } & \multicolumn{3}{|c|}{ OLS } & \multicolumn{3}{|c|}{ WLS } \\
\hline & 2nd HFT & 3rd HFT & 4th + & 2nd HFT & 3rd HFT & 4 th + \\
\hline \multicolumn{7}{|c|}{ Panel A. Treatment Effect: Month 1} \\
\hline HFT & $\begin{array}{l}4.94^{\star \star \star} \\
(5.77)\end{array}$ & $\begin{array}{l}3.30^{\star \star \star} \\
(6.22)\end{array}$ & $\begin{array}{l}2.36^{\star \star \star} \\
(9.92)\end{array}$ & $\begin{array}{l}6.19^{\star \star \star} \\
(5.22)\end{array}$ & $\begin{array}{l}3.72^{* * *} \\
(5.65)\end{array}$ & $\begin{array}{l}2.33^{\star \star *} \\
(8.29)\end{array}$ \\
\hline AFTER & $\begin{array}{l}-0.57 \\
(-1.26)\end{array}$ & $\begin{array}{l}-0.25 \\
(-0.67)\end{array}$ & $\begin{array}{l}-0.23 \\
(-1.16)\end{array}$ & $\begin{array}{l}-0.94^{*} \\
(-1.65)\end{array}$ & $\begin{array}{l}-0.22 \\
(-0.51)\end{array}$ & $\begin{array}{c}0.05 \\
(0.20)\end{array}$ \\
\hline MARKET_CAP & $\begin{array}{c}6.47 \\
(1.00)\end{array}$ & $\begin{array}{l}21.26^{\star \star \star} \\
(6.95)\end{array}$ & $\begin{array}{l}-0.47 \\
(-0.31)\end{array}$ & $\begin{array}{c}9.97 \\
(1.58)\end{array}$ & $\begin{array}{l}20.31^{\star \star *} \\
(6.12)\end{array}$ & $\begin{array}{c}0.37 \\
(0.18)\end{array}$ \\
\hline TSX_VOLUME & $\begin{array}{c}0.31 \\
(1.51)\end{array}$ & $\begin{array}{l}-0.07 \\
(-0.29)\end{array}$ & $\begin{array}{l}-0.62^{\star \star \star} \\
(-3.60)\end{array}$ & $\begin{array}{c}0.45^{\star} \\
(1.85)\end{array}$ & $\begin{array}{c}0.17 \\
(0.71)\end{array}$ & $\begin{array}{l}-0.39^{* *} \\
(-2.03)\end{array}$ \\
\hline PRICE & $\begin{array}{l}0.1 \\
(0.82)\end{array}$ & $\begin{array}{c}0.15 \\
(1.21)\end{array}$ & $\begin{array}{l}-0.08^{\star \star} \\
(-2.10)\end{array}$ & $\begin{array}{l}0.1 \\
(0.69)\end{array}$ & $\begin{array}{l}0.2 \\
(1.47)\end{array}$ & $\begin{array}{l}-0.05 \\
(-0.86)\end{array}$ \\
\hline VOLATILITY & $\begin{array}{l}-0.27^{*} \\
(-1.70)\end{array}$ & $\begin{array}{l}-0.46^{\star \star} \\
(-2.11)\end{array}$ & $\begin{array}{l}-0.17^{\star \star \star} \\
(-3.61)\end{array}$ & $\begin{array}{l}-0.17 \\
(-0.99)\end{array}$ & $\begin{array}{l}-0.67^{\star \star} \\
(-2.52)\end{array}$ & $\begin{array}{l}-0.13^{* *} \\
(-2.29)\end{array}$ \\
\hline NUMBER_OF_FIRMS & $\begin{array}{l}-0.02 \\
(-0.55)\end{array}$ & $\begin{array}{l}0.13^{\star \star \star} \\
(2.59)\end{array}$ & $\begin{array}{l}0.18^{\star \star \star} \\
(6.10)\end{array}$ & $\begin{array}{l}-0.01 \\
(-0.15)\end{array}$ & 0.06 & $0.10^{* * *}$ \\
\hline Fixed effects & Yes & Yes & Yes & Yes & Yes & Yes \\
\hline $\begin{array}{l}R^{2} \\
\text { No. of events }\end{array}$ & $\begin{array}{r}0.679 \\
189\end{array}$ & $\begin{array}{r}0.707 \\
176\end{array}$ & $\begin{array}{c}0.66 \\
643\end{array}$ & $\begin{array}{r}0.657 \\
189\end{array}$ & $\begin{array}{r}0.703 \\
176\end{array}$ & $\begin{array}{r}0.664 \\
643\end{array}$ \\
\hline \multicolumn{7}{|c|}{ Panel B. Treatment Effect: Month 2} \\
\hline HFT & $\begin{array}{l}4.52^{\star \star \star} \\
(4.78)\end{array}$ & $\begin{array}{l}3.78^{\star \star \star} \\
(5.82)\end{array}$ & $\begin{array}{l}2.60^{\star \star \star} \\
(8.70)\end{array}$ & $\begin{array}{l}4.43^{\star \star \star} \\
(3.68)\end{array}$ & $\begin{array}{l}3.87^{\star \star *} \\
(5.25)\end{array}$ & $\begin{array}{l}2.50^{* * \star} \\
(7.31)\end{array}$ \\
\hline \multicolumn{7}{|c|}{ Panel C. Treatment Effect: Month 3} \\
\hline HFT & $\begin{array}{l}5.31^{\star \star \star} \\
(5.63)\end{array}$ & $\begin{array}{l}4.51^{\star \star \star} \\
(6.17)\end{array}$ & $\begin{array}{l}2.77^{\star \star \star} \\
(7.96)\end{array}$ & $\begin{array}{l}6.03^{\star \star \star} \\
(4.81)\end{array}$ & $\begin{array}{l}5.14^{\star \star \star} \\
(5.92)\end{array}$ & $\begin{array}{l}2.67^{\star \star \star} \\
(6.37)\end{array}$ \\
\hline
\end{tabular}


TABLE 11

HFT Competition and HFT Incumbents' Share of Volume

Table 11 reports a difference-in-differences event study on the volume share of high-frequency trader (HFT) incumbents comparing the month before a stock-entry date of an HFT to the first, second, and third months after the date, run separately for the second, third, and fourth and later HFTs to begin trading. HFT_INCUMBENT_VOLUME_SHARE is the percentage of daily volume for which an incumbent HFT (i.e., not the entrant in the treatment stock) is one counterparty. For each treatment stock, a control is matched by Mahalanobis ranking on log market cap, log Toronto Stock Exchange (TSX) volume, price, 10-day price volatility, and absolute bid-ask spread during the month before the event. The regressors are HFT, the treatment dummy; AFTER, the post-period dummy; controls for log market cap (MARKET_CAP), log TSX volume (TSX_VOLUME), price (PRICE), 10-day price volatility (VOLATILITY), and number of traders (NUMBER_OF_FIRMS); and stock-event fixed effects. The event study is fit once using ordinary least squares (OLS) and once using weighted least squares (WLS), in which the weighting is the HFT entrant's volume share during the month. The immediate 1-month entry results are reported in Panel A, the second-month entry HFT coefficient is reported in Panel $\mathrm{B}$, and the third-month entry HFT coefficient is reported in Panel C. ${ }^{*},{ }^{* *}$, and ${ }^{* * *}$ indicate statistical significance at the $10 \%, 5 \%$, and $1 \%$ levels, respectively. $t$-statistics are given in parentheses. Standard errors are double-clustered by stock-event and calendar date.

\begin{tabular}{|c|c|c|c|c|c|c|}
\hline \multirow[b]{2}{*}{ Variable } & \multicolumn{3}{|c|}{ OLS } & \multicolumn{3}{|c|}{ WLS } \\
\hline & 2nd HFT & 3rd HFT & 4 th + & 2nd HFT & 3rd HFT & 4 th + \\
\hline \multicolumn{7}{|c|}{ Panel A. Treatment Effect: Month 1} \\
\hline HFT & $\begin{array}{l}-5.13^{\star \star \star} \\
(-6.78)\end{array}$ & $\begin{array}{r}-0.93^{\star} \\
(-1.91)\end{array}$ & $\begin{array}{c}-0.41^{\star} \\
(-1.82)\end{array}$ & $\begin{array}{l}-5.89^{* * *} \\
(-6.18)\end{array}$ & $\begin{array}{l}-1.10^{*} \\
(-1.84)\end{array}$ & $\begin{array}{l}-0.71^{* * *} \\
(-2.74)\end{array}$ \\
\hline AFTER & $\begin{array}{c}-0.52 \\
(-1.22)\end{array}$ & $\begin{array}{l}-0.76^{\star \star} \\
(-2.11)\end{array}$ & $\begin{array}{l}-0.50^{\star \star} \\
(-2.56)\end{array}$ & $\begin{array}{c}-0.68 \\
(-1.23)\end{array}$ & $\begin{array}{l}-1.04^{\star * *} \\
(-2.71)\end{array}$ & $\begin{array}{l}-0.2 \\
(-0.87)\end{array}$ \\
\hline MARKET_CAP & $\begin{array}{c}2.05 \\
(0.35)\end{array}$ & 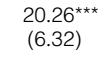 & $\begin{array}{l}-0.3 \\
(-0.18)\end{array}$ & $\begin{array}{c}5.71 \\
(0.99)\end{array}$ & $\begin{array}{l}20.39^{* * *} \\
(6.09)\end{array}$ & $\begin{array}{l}-0.18 \\
(-0.09)\end{array}$ \\
\hline TSX_VOLUME & $\begin{array}{l}0.60^{\star \star \star} \\
(2.88)\end{array}$ & $\begin{array}{c}0.18 \\
(0.76)\end{array}$ & $\begin{array}{l}-0.62^{\star \star \star} \\
(-3.63)\end{array}$ & $\begin{array}{l}0.86^{\star \star \star} \\
(3.45)\end{array}$ & $\begin{array}{c}0.49^{*} \\
(1.95)\end{array}$ & $\begin{array}{l}-0.35^{\star} \\
(-1.81)\end{array}$ \\
\hline PRICE & $\begin{array}{c}0.08 \\
(0.61)\end{array}$ & $\begin{array}{c}0.09 \\
(0.79)\end{array}$ & $\begin{array}{c}-0.04 \\
(-0.82)\end{array}$ & $\begin{array}{c}0.06 \\
(0.34)\end{array}$ & $\begin{array}{l}0.1 \\
(0.88)\end{array}$ & $\begin{array}{c}-0.04 \\
(-0.89)\end{array}$ \\
\hline VOLATILITY & $\begin{array}{l}-0.12 \\
(-0.80)\end{array}$ & $\begin{array}{l}-0.36^{\star} \\
(-1.72)\end{array}$ & $\begin{array}{l}-0.18^{\star \star \star} \\
(-3.03)\end{array}$ & $\begin{array}{l}-0.07 \\
(-0.43)\end{array}$ & $\begin{array}{l}-0.42^{\star} \\
(-1.72)\end{array}$ & $\begin{array}{l}-0.16^{\text {** }} \\
(-2.72)\end{array}$ \\
\hline NUMBER_OF_FIRMS & $\begin{array}{l}-0.01 \\
(-0.37)\end{array}$ & $\begin{array}{l}0.13^{\star \star} \\
(2.52)\end{array}$ & $\begin{array}{l}0.18^{\star \star \star} \\
(5.89)\end{array}$ & $\begin{array}{c}0 \\
(-0.04)\end{array}$ & $\begin{array}{c}0.05 \\
(1.19)\end{array}$ & 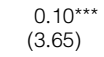 \\
\hline Fixed effects & Yes & Yes & Yes & Yes & Yes & Yes \\
\hline $\begin{array}{l}R^{2} \\
\text { No. of events }\end{array}$ & $\begin{array}{r}0.704 \\
189\end{array}$ & $\begin{array}{r}0.698 \\
176\end{array}$ & $\begin{array}{r}0.665 \\
643\end{array}$ & $\begin{array}{r}0.681 \\
189\end{array}$ & $\begin{array}{r}0.701 \\
176\end{array}$ & $\begin{array}{r}0.673 \\
643\end{array}$ \\
\hline \multicolumn{7}{|c|}{ Panel B. Treatment Effect: Month 2} \\
\hline HFT & $\begin{array}{l}-6.64^{\star \star \star} \\
(-6.20)\end{array}$ & $\begin{array}{c}0.14 \\
(0.22)\end{array}$ & $\begin{array}{l}-0.27 \\
(-0.93)\end{array}$ & $\begin{array}{l}-8.56^{\star \star \star} \\
(-6.23)\end{array}$ & $\begin{array}{l}-0.05 \\
(-0.06)\end{array}$ & $\begin{array}{l}-0.53 \\
(-1.57)\end{array}$ \\
\hline \multicolumn{7}{|c|}{ Panel C. Treatment Effect: Month 3} \\
\hline HFT & $\begin{array}{l}-6.01^{\star \star \star} \\
(-5.17)\end{array}$ & $\begin{array}{c}0.45 \\
(0.64) \\
\end{array}$ & $\begin{array}{c}-0.41 \\
(-1.24) \\
\end{array}$ & $\begin{array}{l}-7.54^{\star \star \star} \\
(-5.17)\end{array}$ & $\begin{array}{c}0.78 \\
(0.92) \\
\end{array}$ & $\begin{array}{r}-0.69^{*} \\
(-1.74) \\
\end{array}$ \\
\hline
\end{tabular}

\section{B. Prices Quoted by Incumbents}

To further test the predictions of quantity competition on prices, we compute the effective spread offered by HFT incumbents. This measure is not the market effective spread but the effective spread for trades in which incumbent HFTs take the passive side. We do not compute the measure for all trades for two reasons: We have already studied a similar metric in Tables 5 and 6 , and moreover, we wish to verify specifically that incumbents react in a way consistent with quantity competition. HFT_INCUMBENT_EFFECTIVE_SPREAD equals twice the distance from the midquote to the execution price in which an HFT incumbent firm is the passive counterparty, divided by the midquote and multiplied by 10,000 so that the measure is in basis points.

Table 12 reports the impact of passive HFT entry on the effective spreads offered by incumbent HFTs only (not the entrant). 
TABLE 12

Passive HFT Competition and HFT Incumbent Effective Spreads

Table 12 reports a difference-in-differences event study on the effective spreads of high-frequency trader (HFT) incumbents comparing the month before a stock-entry date of a passive HFT to the first, second, and third months after the date, run separately for the second, third, and fourth and later HFTs to begin trading. HFT_INCUMBENT_EFFECTIVE_SPREAD is the effective spread of trades in which an incumbent HFT (i.e.. not the entrant in the treatment stock) is the passive counterparty. A passive HFT is an HFT that uses predominantly limit orders to trade. For each treatment stock, a control is matched by Mahalanobis ranking on log market cap, log Toronto Stock Exchange (TSX) volume, price, 10-day price volatility, and absolute bid-ask spread during the month before the event. The regressors are HFT, the treatment dummy; AFTER, the post-period dummy; controls for log market cap (MARKET_CAP), log TSX volume (TSX_VOLUME), price (PRICE), 10-day price volatility (VOLATILITY), and number of traders (NUMBER_OF_FIRMS); and stock-event fixed effects. The event study is fit once using ordinary least squares (OLS) and once using weighted least squares (WLS), in which the weighting is the HFT entrant's volume share during the month. The immediate 1-month entry results are reported in Panel A, the second-month entry HFT coefficient is reported in Panel B, and the third-month entry HFT coefficient is reported in Panel C. ${ }^{*}{ }^{* *}$, and ${ }^{* * *}$ indicate statistical significance at the $10 \%, 5 \%$, and $1 \%$ levels, respectively. $t$-statistics are given in parentheses. Standard errors are double-clustered by stock-event and calendar date.

\begin{tabular}{|c|c|c|c|c|c|c|}
\hline \multirow[b]{2}{*}{ Variable } & \multicolumn{3}{|c|}{ OLS } & \multicolumn{3}{|c|}{ WLS } \\
\hline & 2nd HFT & 3rd HFT & 4 th + & 2nd HFT & 3rd HFT & 4 th + \\
\hline \multicolumn{7}{|c|}{ Panel A. Treatment Effect: Month 1} \\
\hline HFT & $\begin{array}{l}-36.61^{\star \star \star} \\
(-4.52)\end{array}$ & $\begin{array}{l}-3.02^{\star \star} \\
(-2.14)\end{array}$ & $\begin{array}{l}-0.2 \\
(-0.31)\end{array}$ & $\begin{array}{l}-52.81^{\star \star \star} \\
(-4.53)\end{array}$ & $\begin{array}{l}-4.04^{\star} \\
(-1.84)\end{array}$ & $\begin{array}{c}0.62 \\
(0.61)\end{array}$ \\
\hline AFTER & $\begin{array}{c}5.93 \\
(0.73)\end{array}$ & $\begin{array}{c}1.17 \\
(0.91)\end{array}$ & $\begin{array}{c}0.62 \\
(0.88)\end{array}$ & $\begin{array}{c}8.28 \\
(0.76)\end{array}$ & $\begin{array}{c}0.75 \\
(0.40)\end{array}$ & $\begin{array}{c}0.4 \\
(0.38)\end{array}$ \\
\hline MARKET_CAP & $\begin{array}{l}-12.67 \\
(-0.52)\end{array}$ & $\begin{array}{l}-38.71 \\
(-1.08)\end{array}$ & $\begin{array}{l}-3.62 \\
(-0.82)\end{array}$ & $\begin{array}{l}-25.4 \\
(-0.53)\end{array}$ & $\begin{array}{l}-23.18 \\
(-1.13)\end{array}$ & $\begin{array}{l}-3.99 \\
(-0.82)\end{array}$ \\
\hline TSX_VOLUME & $\begin{array}{c}1.14 \\
(0.41)\end{array}$ & $\begin{array}{c}1.65 \\
(1.32)\end{array}$ & $\begin{array}{l}-0.46 \\
(-0.40)\end{array}$ & $\begin{array}{c}0.44 \\
(0.10)\end{array}$ & $\begin{array}{l}2.17 \\
(1.05)\end{array}$ & $\begin{array}{c}0.38 \\
(0.24)\end{array}$ \\
\hline PRICE & $\begin{array}{l}-1.07 \\
(-1.06)\end{array}$ & $\begin{array}{l}-0.60^{\star \star \star} \\
(-2.87)\end{array}$ & $\begin{array}{l}-0.14^{\star \star} \\
(-2.07)\end{array}$ & $\begin{array}{l}-2.09 \\
(-1.48)\end{array}$ & $\begin{array}{l}-0.66^{\star \star} \\
(-2.50)\end{array}$ & $\begin{array}{l}-0.07 \\
(-0.71)\end{array}$ \\
\hline VOLATILITY & $\begin{array}{l}-1.84 \\
(-1.32)\end{array}$ & $\begin{array}{l}2.37^{\text {***}} \\
(2.65)\end{array}$ & $\begin{array}{c}0.77^{\star \star} \\
(2.07)\end{array}$ & $\begin{array}{l}-2.31 \\
(-1.06)\end{array}$ & $\begin{array}{l}2.45^{\star \star} \\
(2.14)\end{array}$ & $\begin{array}{l}1.36^{* *} \\
(2.27)\end{array}$ \\
\hline NUMBER_OF_FIRMS & $\begin{array}{l}-2.43^{\star \star \star} \\
(-4.39)\end{array}$ & $\begin{array}{l}-0.37^{\star *} \\
(-2.52)\end{array}$ & $\begin{array}{l}-0.21^{\star \star \star} \\
(-3.51)\end{array}$ & $\begin{array}{l}-3.25^{\star \star \star} \\
(-4.21)\end{array}$ & $\begin{array}{l}-0.43^{\star} \\
(-1.83)\end{array}$ & $\begin{array}{l}-0.39^{* \star \star} \\
(-2.94)\end{array}$ \\
\hline Fixed effects & Yes & Yes & Yes & Yes & Yes & Yes \\
\hline $\begin{array}{l}R^{2} \\
\text { No. of events }\end{array}$ & $\begin{array}{r}0.364 \\
140\end{array}$ & $\begin{array}{r}0.605 \\
122\end{array}$ & $\begin{array}{r}0.607 \\
298\end{array}$ & $\begin{array}{l}0.35 \\
140\end{array}$ & $\begin{array}{r}0.527 \\
122\end{array}$ & $\begin{array}{r}0.608 \\
298\end{array}$ \\
\hline \multicolumn{7}{|c|}{ Panel B. Treatment Effect: Month 2} \\
\hline HFT & $\begin{array}{l}-38.20^{\star \star \star} \\
(-3.30)\end{array}$ & $\begin{array}{l}-5.14^{\star \star} \\
(-2.33)\end{array}$ & $\begin{array}{l}-1.66 \\
(-0.97)\end{array}$ & $\begin{array}{l}-52.08^{\star \star \star} \\
(-3.13)\end{array}$ & $\begin{array}{l}-7.85^{\star \star} \\
(-2.44)\end{array}$ & $\begin{array}{l}-1.29 \\
(-0.58)\end{array}$ \\
\hline \multicolumn{7}{|c|}{$\underline{\text { Panel C. Treatment Effect: Month } 3}$} \\
\hline HFT & $\begin{array}{l}-30.83^{\star \star \star} \\
(-3.61)\end{array}$ & $\begin{array}{r}-4.70^{\star} \\
(-1.89) \\
\end{array}$ & $\begin{array}{l}-1.11 \\
(-0.99) \\
\end{array}$ & $\begin{array}{l}-44.32^{\star \star \star} \\
(-3.13)\end{array}$ & $\begin{array}{l}-7.00^{\star \star} \\
(-2.41) \\
\end{array}$ & $\begin{array}{l}-0.97 \\
(-0.66) \\
\end{array}$ \\
\hline
\end{tabular}

Consistent with quantity competition, after a passive entry event, HFT incumbents supply tighter effective spreads. They do so after the second entrant and after the third: They tighten their spreads by $37 \mathrm{bps}$ after the second and by $3 \mathrm{bps}$ after the third. There is no statistically significant impact for the fourth and later entrants, which is consistent with limits to price competition on an order book due to the minimum tick size. These impacts are long-lived during the 3 months of the study. In fact, the impact intensifies in the third month for the second and third entrants.

The results on incumbent pricing are consistent with beneficial competitive pressure in markets with more HFTs. Entry tends to lead incumbents to improve prices. As Table 10 shows, entrants seize trading volume from incumbents; the behavior of incumbents is consistent with a competitive response to losses in market share. 


\section{Conclusions}

This article presents three streams of evidence that HFT competition improves liquidity on stocks. First, we provide graphical evidence that suggests the effect. As competition intensifies, the bid-ask spread at an alternative equity market improves and converges to the spread at the national stock market. Second, we use a DID event-study methodology to identify the treatment effect of HFT competition. The event study compares liquidity metrics on the stock market before and after dates on which HFTs begin trading a stock, and for control observations, we use contemporaneous stocks that experienced no HFT entry. We find that the effective and realized spreads for non-HFT participants (the "clients" of HFTs) improve after passive HFT entry dates and weakly improve after aggressive HFT entry dates. Our results are based on the Canadian Alpha exchange and our empirical definition of an HFT; we leave it to future research to determine whether the results hold true in other settings.

The evidence contrasts with some predictions found in theoretical models that feature HFT competition. For instance, some models predict that HFT competition creates illiquidity (Menkveld and Zoican (2017), Budish et al. (2015)). To explain the contrast, we examine the models' assumptions on competition. A tractability assumption of these models is that an HFT is a price competitor. The assumption is key to model results because it eliminates benefits to competition beyond the second firm, leaving only costs to contribute for additional HFTs. We find that quantity competition is a better assumption for HFT competition by testing three predictions of quantity competition that are implausible outcomes from the perspective of a model assuming price competition.

\section{Supplementary Material}

Supplementary Material for this article is available at https://doi.org/10.1017/ S0022109018001175.

\section{References}

Aït-Sahalia, Y., and M. Sağlam. "High Frequency Market Making: Optimal Quoting." Working Paper, available at https://ssrn.com/abstract=2331613 (2013).

Baron, M. D.; J. Brogaard; B. Hagströmer; and A. A. Kirilenko. "Risk and Return in High-Frequency Trading." Journal of Financial and Quantitative Analysis, 54 (2019), 993-1024.

Bertrand, M.; E. Duflo; and S. Mullainathan. "How Much Should We Trust Differences-in-Differences Estimates?" Quarterly Journal of Economics, 119 (2004), 249-275.

Biais, B.; T. Foucault; and S. Moinas. "Equilibrium Fast Trading." Journal of Financial Economics, 116 (2015), 292-313.

Biais, B.; D. Martimort; and J. C. Rochet. "Competing Mechanisms in a Common Value Environment." Econometrica, 68 (2000), 799-837.

Boehmer, E.; D. Li; and G. Saar. "The Competitive Landscape of High-Frequency Trading Firms." Review of Financial Studies, 31 (2018), 2227-2276.

Bondarenko, O. "Competing Market Makers, Liquidity Provision, and Bid-Ask Spreads." Journal of Financial Markets, 4 (2001), 269-308.

Breckenfelder, J. H. "Competition between High-Frequency Traders, and Market Quality." Munich Personal RePEc Archive Working Paper (2013).

Bresnahan, T. F. "Empirical Studies of Industries with Market Power." In Handbook of Industrial Organization, Vol. 2, R. Schmalensee and R. Willig, eds. Amsterdam, Netherlands: Elsevier (1989).

Brogaard, J.; T. Hendershott; and R. Riordan. "High-Frequency Trading and Price Discovery." Review of Financial Studies, 27 (2014), 2267-2306. 
Budish, E. B.; P. Cramton; and J. J. Shim. "The High-Frequency Trading Arms Race: Frequent Batch Auctions as a Market Design Response." Quarterly Journal of Economics, 130 (2015), 1547-1621.

Ellis, K.; R. Michaely; and M. O’Hara. “The Making of a Dealer Market: From Entry to Equilibrium in the Trading of Nasdaq Stocks.” Journal of Finance, 57 (2002), 2289-2316.

Fischer, S. "Is There a Liquidity Problem Post-Crisis?" Speech at the Initiative on Business and Public Policy at the Brookings Institution, Washington, DC (Nov. 15, 2016).

Ho, T., and H. R. Stoll. "On Dealer Markets under Competition." Journal of Finance, 35 (1980), 259-267.

Hoffmann, P. "A Dynamic Limit Order Market with Fast and Slow Traders." Journal of Financial Economics, 113 (2014), 156-169.

Jones, C. M. "What Do We Know about High-Frequency Trading?" Working Paper, Columbia University (2013).

Kirilenko, A.; A. S. Kyle; M. Samadi; and T. Tuzun. "The Flash Crash: High-Frequency Trading in an Electronic Market.” Journal of Finance, 72 (2017), 967-998.

Kyle, A. S. "Informed Speculation with Imperfect Competition." Review of Economic Studies, 56 (1989), 317-355.

Menkveld, A. J. "High Frequency Trading and the New Market Makers." Journal of Financial Markets, 16 (2013), 712-740.

Menkveld, A. J., and M. A. Zoican. "Need for Speed? Exchange Latency and Liquidity." Review of Financial Studies, 30 (2017), 1188-1228.

O'Hara, M.; G. Saar; and Z. Zhong. "Relative Tick Size and the Trading Environment." Review of Asset Pricing Studies, forthcoming (2019).

Petersen, M. A. "Estimating Standard Errors in Finance Panel Data Sets: Comparing Approaches." Review of Financial Studies, 22 (2009), 435-480.

Subrahmanyam, A. "Risk Aversion, Market Liquidity, and Price Efficiency." Review of Financial Studies, 4 (1991), 417-441.

Thompson, S. B. "Simple Formulas for Standard Errors That Cluster by Both Firm and Time." Journal of Financial Economics, 99 (2011), 1-10.

Tirole, J. The Theory of Industrial Organization. Cambridge, MA: MIT Press (1988). 